NBER WORKING PAPER SERIES

\title{
THE ROOTS OF LATIN AMERICAN PROTECTIONISM: LOOKING BEFORE THE GREAT DEPRESSION
}

\author{
John H. Coatsworth \\ Jeffrey G. Williamson \\ Working Paper 8999 \\ http://www.nber.org/papers/w8999
NATIONAL BUREAU OF ECONOMIC RESEARCH
1050 Massachusetts Avenue
Cambridge, MA 02138
June 2002

Paper to be presented to an IDB conference on Economic Integration in the Americas: Prospects and Policy Issues (Punta del Este, November 2002). Much of the tariff data used in this paper has been taken from a collaboration between the second author and Michael Clemens, and we are grateful to the latter for allowing us to use that data here too. We have also received superb research assistance from Chris Blattman and István Zöllei. In addition, we have benefitted from conversations with Richard Cooper, Ron Findlay, Jeff Frieden, Steve Haber, Elhanan Helpman, Doug Irwin, Dani Rodrik, Dick Salvucci, Alan Taylor, and participants at joint development, international and history workshops at Copenhagen, Harvard and Yale. Remaining errors belong to us. Williamson acknowledges with pleasure financial support from the National Science Foundation SES-0001362. The views expressed herein are those of the authors and not necessarily those of the National Bureau of Economic Research.

(C) 2002 by John H. Coatsworth and Jeffrey G. Williamson. All rights reserved. Short sections of text, not to exceed two paragraphs, may be quoted without explicit permission provided that full credit, including (C) notice, is given to the source. 
The Roots of Latin American Protectionism:

Looking Before the Great Depression

John H. Coatsworth and Jeffrey G. Williamson

NBER Working Paper No. 8999

June 2002

JEL No. F1, N7, O2

\begin{abstract}
This paper uncovers a fact that has not been well appreciated: tariffs in Latin America were far higher than anywhere else in the century before the Great Depression. This is a surprising fact given that this region has been said to have exploited globalization forces better than most during the pre-1914 belle epoque and for which the Great Depression has always been viewed as a critical policy turning point towards protection and de-linking from the world economy. This paper shows that the explanation cannot lie with output gains from protection, since, while such gains were present in Europe and its non-Latin offshoots, they were not present in Latin America. The paper then explores Latin American tariffs as a revenue source, as a protective device for special interests, and as the result of other political economy struggles. We conclude by asking whether the same pro-protection conditions exist today as those which existed more than a century ago.
\end{abstract}

John H. Coatsworth Department of History Harvard University Cambridge, MA 02138 and Center for Latin American Studies coatswor@fas.harvard.edu
Jeffrey G. Williamson Department of Economics Harvard University Cambridge, MA 02138 and NBER and Center for International Development jwilliam@harvard.edu 


\section{The Issues}

This paper uncovers a fact that has not been well appreciated. Tariffs in Latin America were far higher than anywhere else in the world from the 1860s to World War I, long before the Great Depression. Indeed, they were even rising in the decades before 1914, a period that has been called the first globalization boom for the world economy (O'Rourke and Williamson 1999). This fact is surprising, and for three reason. First, it comes as a surprise given that this region has been said to have exploited globalization forces better than most during the pre-1914 belle epoque. Second, it comes as a surprise since standard economic histories say so little about it. Third, it comes as a surprise to most of us who have always been taught to view the Great Depression as the critical turning point when the region is said to have turned towards protection and de-linked from the world economy for the first time.

After establishing the fact, the paper then shows that its explanation cannot lie with some perceived GDP per capita gains from protection, since, while such gains were certainly present in industrial Europe and its non-Latin offshoots (Clemens and Williamson 2001), they most definitely were not present in Latin America. On the contrary, those who had the highest tariff rates in Latin America grew the slowest, and those who had the lowest tariff rates grew fastest. The paper then explores Latin American tariffs as a revenue source, as a protective device for special interests, and as a consequence of

other political economy struggles. While the exploration is mostly qualitative for the first half century of independence, it is quite quantitative for the period 1870-1950, using annual data for a sample of eight Latin American countries treated both as a panel and with country fixed effects.

Historical persistence has mattered for Latin America, and we conclude by asking whether the same pro-protection conditions exist today as those which existed more than a century ago. 


\section{The Big Fact: Latin America Was the World's Most Protectionist Region in the Belle Epoque!}

There is a well-developed literature that debates how to measure openness (e.g., Anderson and Neary 1994; Sachs and Warner 1995; Anderson 1998). That literature makes it clear that trade shares are poor measures of openness since they are endogenous. ${ }^{1}$ Among the explicit policy measures of openness available, the average tariff rate is by far the most homogenous protection measure and the easiest to collect across countries and over time. ${ }^{2}$ This paper uses the computed average tariff rate to explore the policy experience of 8 Latin American countries compared with 27 others the world around between 1865 and World War II: the United States; 3 members of the European industrial core (France, Germany, United Kingdom); 3 non-Latin European offshoots (Australia, Canada, New Zealand); 10 from the European periphery (Austria-Hungary, Denmark, Greece, Italy, Norway, Portugal, Russia, Serbia, Spain, Sweden); 10 from Asia and the Mideast (Burma, Ceylon, China, Egypt, India, Indonesia, Japan, the Philippines, Siam, Turkey) and 8 from Latin America (Argentina, Brazil, Chile, Cuba, Colombia, Mexico, Peru, Uruguay).

Figure 1 plots average world tariffs before World War II (unweighted and weighted by export shares in world markets), and Figures $2 \mathrm{a}$ and $2 \mathrm{~b}$ plot it for some regional clubs. ${ }^{3}$ There are five regions plus the US plotted there - US, European core, European periphery, European non-Latin offshoot, Asia and Latin America - the country members of which have already been identified above.

1 Indeed, it appears that fully two-thirds of the late $20^{\text {th }}$ century trade boom involving the OECD can be explained by unusually fast income growth, not by the decline in trade barriers (Baier and Bergstrand 2001). To cite another example, it also appears that two-thirds of the European overseas trade boom in the three centuries following 1492 were also driven by income growth, rather than by any decline in trade barriers (O'Rourke and Williamson 2002).

2 The average tariff rate is measured here as customs revenues (import duties only) as a share of total import values.

3 Like Figure 1, we have also calculated (but do not report) weighted tariff averages for the regional clubs in Figures $2 \mathrm{a}$ and $2 \mathrm{~b}$, where weights are the country's total export share in regional exports or its GDP share. However, we prefer to treat countries as independent policy units regardless of size. The complete data base used in this paper is described at length in the Appendix. 
First, note in Figure 1 the protectionist drift worldwide between 1865 and World War I, a modest anti-globalization backlash if you will, registering a slow retreat from the liberal pro-global trade positions in mid-century (Williamson 1998). The surge to world protection in the 1920s and 1930s is, of course, better known.

Second, note too the enormous variance in levels of protection between the regional club averages. The richer new world European offshoots had levels of protection twice that of the European core around the turn of the last century. When the US is shifted to the rich European offshoot club, the ratio of tariffs between European offshoot and core jumps to more than three times. To take another example, in 1925 the European periphery had tariffs 2.4 times higher than those in the European part of the industrial core. To take yet another example, in 1885 the poor but independent parts of Latin America (Brazil, Colombia, Mexico and Peru) had tariffs 4.6 times higher than those in the poor and dependent parts of Asia (Burma, Ceylon, China, Egypt, India, Indonesia and the Philippines).

Third, there was as well great variance within these regional clubs. In 1905, tariffs in Uruguay (the most protectionist land-abundant and labor-scarce country: Figure 4) were about two and a half times those in Canada (the least protectionist land-abundant and labor-scarce country). In the same year, tariffs in Brazil and Colombia (the most protectionist Latin American countries) were almost ten times those in China and India (the least protectionist in Asia). The same high-low range appeared among the industrial core countries (the US five times the UK) and the European periphery (Russia six times AustriaHungary). Thus, explaining differences between countries before 1940 will be at least as challenging as explaining changes in tariff policy over the eight decades after 1865, perhaps more so. And this observation applies with special force to Latin America where the range around World War I was from a little more than 10 percent in Chile to about 55 percent in Columbia (Figure 4).

Finally, note the really big fact that motivates this paper: We are taught that the Latin American reluctance to go open in the late $20^{\text {th }}$ century was the product of the Great Depression and the de-linking import substitution strategies that arose to deal with it (Diaz-Alejandro 1984; Corbo 1992; Taylor 1998). Yet, $19^{\text {th }}$ century Latin America - whether our poor four (Brazil, Colombia, Mexico, Peru), our rich three in the southern cone (Argentina, Chile, Uruguay) or even Cuba - already had by far the highest tariffs in 
the world (Figure 2a). With the exception of the US, Latin American tariffs were the highest in the world by 1865 . At the crescendo of the belle epoque, Latin American tariffs were at their peak, and still way above the rest of the world. Apparently, the famous export-led growth spurt in Latin America wasn't inconsistent with enormous tariffs. (But they might have done even better without them.) Latin American tariffs were still the world's highest in the 1920s, although the gap between Latin America and the rest had shrunk considerably (Figure 3). Oddly enough, it was in the 1930s that the rest of the world (the European Core and Asia) finally surpassed Latin America in securing the dubious distinction of being the most protectionist. By the 1950s, and when ISI policies were flourishing, Latin American tariffs were actually lower than those in Asia and the European periphery. ${ }^{4}$ Thus, whatever explanations are offered for the Latin American commitment to protection, we must search for its origin well before the Great Depression. Indeed, it seems that there was nothing at all precocious about Latin American de-linking in the 1930 s since protectionist barriers had been higher there than anywhere else for 60 years, and, as we shall show below, perhaps even for 100 years.

The empirical analysis later in this paper will treat Latin American countries as the unit of observation, but for now let's simply look further at the experience of the regional clubs to better place Latin American experience in world perspective. Prior to World War I, tariffs were much higher in both the non-Latin and the Latin European offshoots than anywhere else. Furthermore, and as we have already mentioned, they would have been even higher had we allocated to the non-Latin offshoot club one of the most-protectionist, the US. The European members of the core (France, Germany, UK) had the lowest tariffs. Much of Asia and the Mideast were colonies or quasi-colonies of the core (Burma, Ceylon, Egypt, India, Indonesia, the Philippines), or were forced to sign free trade agreements with the core since the latter had naval guns trained on their potential trading partners (China, Japan), or viewed nearby gunboats as a sufficient threat to go open on their own (Siam). Thus, the Asia tariff rates are pretty much like those of the European core early on, but they start drifting towards protection after the 1880 s, long before the

\footnotetext{
4 This finding - higher levels of protection in Asia than in Latin America before the 1970s, is confirmed by Alan Taylor (1998: Table 2, p. 7) even when more comprehensive measures of protection and openness are employed that include non-tariff barriers.
} 
Third World independence movement after World War II. This protectionist drift in the periphery is illustrated best by events in poor Latin America (Brazil, Colombia, Mexico), but from the early 1890s to 1929 the drift to protection is also apparent in many parts of Asia (in particular, Japan, the Philippines and Siam).

In 1865, Asia had the lowest tariffs, but they soar in the interwar years, mimicking their colonial masters. The European periphery leaps to high levels of protection after the 1870 s, with Russian protectionist policy leading the way (along with Greece and, to a lesser extent, Serbia). There is plenty of evidence of rising world protection before World War I (the unweighted average in the full sample rising from about 12 percent in 1865 to about 17 percent in 1910), and this drift towards more protection appeared everywhere except the European core and the US (where there was a slow retreat from its enormous Civil War tariffs), but the protectionist drift took place mainly in Latin America, the non-Latin European offshoots and the European periphery. Who was leading the backlash early in the period, say, between 1870 and 1890 ? Columbia and Russia were way ahead of the pack, with tariff rate increases of 20 percentage points or more; other backlash leaders with 5 to 12 percentage point increases were Argentina, Canada, Chile, New Zealand and Uruguay - all rich Latin and non-Latin European offshoots, plus a regional mixture containing Egypt, Greece, and Peru (Clemens and Williamson 2002: Figure 3), as well as some European continentals who just make it over the 5 percentage point increase bar -- France, Germany, Italy, Portugal and Spain. There is also evidence of a worldwide reversal of the pre-war drift towards protection after the 1890s, including Latin America (but not Brazil and Colombia: Figure 4).

There are some surprises in these tariff data that have not been noticed by those who have concentrated on one epoch, one region or even just one country. This paper stresses the big Latin American surprise: Latin America had the highest tariffs the world as early as 1865, a "leadership" position it held until the 1930s when Europe and others took over this dubious leadership. The second big surprise involving Latin America is this: the traditional literature written by European economic historians has made much of the tariff backlash on the continent after the 1870s (Kindleberger 1951; Bairoch 1989; O'Rourke and Williamson 1999). Yet, the rise in the average tariff rate between the 1870s and the 1890 s was 5.7 percentage points in France, up from 4.4 to still only 10.1 percent, and 5.3 
percentage points in Germany, up from 3.8 to still only 9.1 percent. This heavily-researched continental move to protection is pretty small potatoes when compared with the rise over the same period in our four poor Latin American countries (up 6.9 percentage points to 34 percent), and this for a region which has been said to have exploited the pre-1914 globalization boom so well.

In the interwar decades, tariffs took two big leaps upward, and these took place world wide. The first leap was in the 1920s, which might be interpreted as a policy effort to return to 1914 levels. It might also be due to postwar deflation. Inflations and deflations seem to have influenced tariff rates in the 1910s, the 1920s and some other times, an effect to which we return later in this paper, and one which gets the label specific-duty-inflation-deflation effect.

The second interwar leap in tariff rates was, of course, in the 1930s, with aggressive beggar-myneighbor policies reinforced by the specific-duty-inflation-deflation effect. In the industrial core, the biggest interwar tariff hikes were Germany and the UK, but France and the US were not far behind. While Scandinavia showed restraint, the rest of the European periphery did not. With the exception of protectionist Australia, the English-speaking European offshoots showed restraint. Tariffs rose everywhere in Latin America, except two that had the highest pre-war tariffs, Colombia and Uruguay. Tariffs rose across the interwar decades in Asia and the Mideast, and the rise was especially dramatic in Burma, Ceylon, China, Egypt, India, Siam and Turkey, so much so that Asia joined the European Core as the most protectionist parts of the world.

History offers exactly the policy variance we need to learn more about the political economy of tariffs. ${ }^{5}$ And nowhere were tariffs higher than they were in Latin America, and nowhere did they vary as much within the club as they did within Latin America (Figure 4).

So, what was the political economy that determined Latin American protection in the century before the end of the Great Depression?

5 Most empirical studies in the new endogenous tariff literature appeal to evidence created by the variance across US industries in some given year (e.g. Grossman and Helpman 1994; Goldberg and Maggi 1999) or US time series (e.g. Magee and Young 1987; Magee, Brock and Young 1989). 


\section{Protection Did Not Foster Economic Growth in Latin America}

Does protection help or hinder growth? We need to answer this question first to see whether Latin American policy makers could have used this argument in the $19^{\text {th }}$ century to support their protectionist policies. 6

Let's start with the familiar late $20^{\text {th }}$ century evidence. It is unambiguous on the issue, and it can be found in four kinds of studies. ${ }^{7}$

First, the authors of a large National Bureau of Economic Research project assessed trade and exchange-control regimes in the 1960s and 1970s by making classic partial-equilibrium calculations of deadweight losses (Bhagwati and Krueger 1973-1976). They concluded that the barriers imposed significant costs in all but one case. However, these standard welfare calculations have been criticized by those who have pointed out that, in such studies, protection is not allowed a chance to lower long-run cost curves, as in the traditional infant-industry case (Baldwin 1969), or to foster industrialization and thus growth, as in those modern growth models where industry is the carrier of technological change and capital deepening. Thus, economists have had to look for more late $20^{\text {th }}$ century proof to support the openness-fosters-growth hypothesis.

Second, analysts have contrasted the growth performance of relatively open with relatively closed economies. The World Bank has conducted such studies for 41 countries going back before the first oil shock. The correlation between trade openness and growth is abundantly clear in these studies (Lindert and Williamson 2001: Table 3), but the analysis is vulnerable to the criticism that the effect of trade policies alone cannot be isolated since other policies usually change at the same time. Thus, countries that liberalized their trade also liberalized their domestic factor markets, liberalized their domestic commodity markets, and set up better property-rights enforcement. The appearance of these domestic policies may

\footnotetext{
6 Policy makers of that time didn't have the models, methods and evidence that we exploit in Table 1, but they certainly had the intuition.

7 This section draws on a recent survey paper by Peter Lindert and Jeffrey Williamson (2001) and some new work on the impact of tariffs on growth before 1950 (Clemens and Williamson 2001).
} 
deserve more credit for raising income while the simultaneous appearance of more liberal trade policies may deserve less.

Third, there are country event studies, where the focus is on periods when trade policy regimes change dramatically enough to see their effect on growth. For example, Anne Krueger $(1983,1984)$ looked at trade opening moments in South Korea around 1960, Brazil and Colombia around 1965, and Tunisia around 1970. Growth improved after liberalization in all four cases. More recently, David Dollar and Aart Kraay (2000) examined the reforms and trade liberalizations of 16 countries in the 1980s and 1990s, finding, once again, the positive correlation between freer trade and faster growth. Of course, these reform episodes may have changed more than just global participation, so that an independent trade effect may not have been isolated.

Fourth, macro-econometric analysis has been used in an attempt to resolve the doubts left by simpler historical correlations revealed by the other three kinds of studies. This macro-econometric literature shows that free trade policies have had a positive effect on growth in the late $20^{\text {th }}$ century, especially with many other relevant influences held constant. The most famous of these is by Jeffrey Sachs and Andrew Warner (1995), but many others have also confirmed the openness-fosters-growth hypothesis for the late $20^{\text {th }}$ century (e.g. Dollar 1992; Edwards 1993; Bloom and Williamson 1998; Dollar and Kraay 2000).

If free trade has encouraged (or at least has not harmed: pace Rodriguez and Rodrik 1999) growth since World War II, why was it bad for growth before? About thirty years ago, Paul Bairoch (1972) argued that protectionist countries grew faster in the $19^{\text {th }}$ century, not slower as every economist has found for the late $20^{\text {th }}$ century. Bairoch's sample was mainly from the European industrial core, it looked at pre-1914 experience only, and it invoked unconditional analysis, controlling for no other factors. Like the second group of modern studies listed above, it simply compared growth rates of major European countries in protectionist and free trade episodes. More recently, Kevin O'Rourke (2000) got the Bairoch finding again, this time using macro-econometric conditional analysis on a ten country sample drawn from the pre-1914 Atlantic economy (Australia, Canada, Denmark, France, Germany, Italy, Norway, 
Sweden, UK, US). In short, these two scholars were not able to find any evidence before World War I supporting the openness-fosters-growth hypothesis. ${ }^{8}$

These pioneering historical studies suggest that there is a tariff-growth paradox out there which took the form of a regime switch somewhere between the start of World War I and the end of World War II: before the switch, protection fostered growth; after the switch, protection hindered growth. Was Latin America part of this paradox, or was it only an attribute of the industrial core? Recent work by Michael Clemens and one of the present authors (Clemens and Williamson 2001) has shown that protection did foster growth in the industrial core before World War II, but that it did not do so in most of the periphery. Table 1 offers a revised version of the Clemens-Williamson result, where the model estimated is of the convergence variety, ${ }^{9}$ but it is conditioned only by the country's own tariff rate and regional club dummies. The tariff rate and GDP per capita level are both measured at year $t$, while the subsequent GDP per capita growth rate is measured over the half decade following. Thus, the last pre-World War II observation is 1934, which relates to growth between 1934 and 1939, and the last pre-World War I observation is 1908 , which relates to the growth between 1908 and 1913. The two world wars are ignored.

The tariff-growth paradox is stunningly clear in Table 1. In columns (1) and (3), the estimated coefficient on $\log$ of the tariff rate is 0.14 for $1875-1908$ and 0.36 for 1924-1934. Thus, and in contrast with late $20^{\text {th }}$ century evidence, tariffs were associated with fast growth before 1939 . But was this true for all regions, or was there instead an asymmetry between industrial economies in the core and primaryproducers in the periphery? Presumably, the protecting country has to have a big domestic market, and has to be ready for industrialization, accumulation, and human capital deepening if the long run tariff-

8 There are three other studies worth mentioning here. Capie (1983) explored the Bairoch hypothesis with a pre1914 European sample of four (Germany, Italy, the UK and Russia), using event analysis. Alfred Eckes (1995) attempted to establish causation from high tariffs to fast growth for $19^{\text {th }}$ century United States, although his work is assiduously criticized by Irwin (2001a). Vamvakidis (1997) couldn't find any interwar evidence supporting the openness-fosters-growth hypothesis either, although it was (once again) based on a small, mostly OECD sample.

9 Note that the estimation in Table 1 reports negative coefficients on log initial GDP per capita after 1924, thus supporting conditional convergence. However, those big negative and significant coefficients on the Asian dummy throughout, on the European periphery dummy throughout, and on the Latin American dummy in the interwar speak far better to unconditional world divergence ("big time": Pritchett 1997) which took place over most of this century. 
induced dynamic effects are to offset the short run gains from trade given up. Table 1 tests for asymmetry in columns (2) and (4), and the asymmetry hypothesis wins, and in the Latin American case especially if we focus on the pre-World War I decades. That is, protection was associated with faster growth in the European core and their English-speaking offshoots (the coefficient on own tariff 1875-1908 is 0.56 and highly significant), but it was not associated with fast growth in the European or Latin American periphery, nor was it associated with fast growth in interwar Asia. Most important, note that before World War I protection in Latin America was associated significantly and powerfully with slow growth.

The moral of the story is while Latin American policy makers may, after the 1860 s, have been aware of the pro-protectionist infant-industry argument ${ }^{10}$ offered for Germany by Frederich List, for federalist United States by Alexander Hamilton, and for ante-bellum United States by Henry Clay, there is absolutely no evidence which would have supported those arguments for Latin America. We must look elsewhere for plausible explanations for the exceptionally high tariffs in Latin America long before the Great Depression.

\section{The Political Economy of Latin American Tariffs: War, Insurrection and Tariffs for Revenue Maximization}

\section{The "Protectionist” Stage Is Set: The First Half-Century of Independence}

In young, recently independent economies with low or even declining capacity to tax income, expenditure or wealth, few bureaucratic resources to implement efficient collection, and limited access to foreign capital markets, customs revenues are an easy-to-collect source of revenues essential to support central government expenditures on infrastructure and defense. ${ }^{11}$ This was certainly true of the newly-

10 And late $19^{\text {th }}$ century Latin American policy makers were certainly were so aware (Bulmer-Thomas 1994: 140). However, it is important to stress "late" since the use of protection specifically and consciously to foster industry does not appear to occur until well after the 1860s: e.g. Argentina with the 1876 tariff; Mexico by the early 1890s; Chile with its new tariff in 1897; Brazil in the 1890s; and Colombia in early 1900s (influenced by Mexican experience). True, Mexico saw some precocious efforts in the late 1830s and 1840s to promote modern industry, but these lapsed with renewed local and international warfare. So, the qualitative evidence suggests that domestic industry protection becomes a motivation for Latin American tariffs only in the late $19^{\text {th }}$ century.

${ }_{11}$ A century later, things had changed, at least with the appearance of the money doctor, Princeton Professor Edwin Kemmerer, and his team of young economists (including Kossuth M. Williamson: see Drake 1989). 
independent United States and Latin American countries in the first half of the $19^{\text {th }}$ century, ${ }^{12}$ although the US had more success in gaining access to European capital markets. The average share of customs duties in total revenues across eleven Latin American republics was 57.8 percent between 1820 and 1890 (Centeno 1997: Table 1). Customs revenues were even more important for federal governments (65.6 percent), since local and state governments who form the union typically are reluctant to give up their limited tax weapons. Furthermore, customs revenues are especially important for land-abundant countries with federal governments since they do not have the population and tax-payer density to make other forms of tax collection efficient. Now add to this a huge revenue need to fight wars and we get the high United States civil war tariffs in the early 1860s and the high (and rising) tariffs in a newly independent Latin America that experienced almost continuous war and civil strife between the 1820 s and the 1870 s. Mares (2001) reports 10 major wars between 1825 and 1879, but limits his data to conflicts that produced at least 1,000 battlefield deaths. Centeno (1997) has counted 33 major international and civil wars between 1819 and 1880, but his data excludes Cuba altogether as well as numerous small and medium-scale internal conflicts and a number of costly international wars. Of the eight countries for which we have data on levels of protection, all fought at least two major wars between independence and 1880. Only Brazil and Chile (after 1830) avoided violent military coups. All of the eight cases experienced episodes of massive and prolonged civil strife. In six countries, internal civil wars raged more or less continuously for decades after independence.

The universal preoccupation with national defense and internal security pushed the newly independent Latin American countries toward higher revenue-maximizing tariffs. Military expenditures quickly rose to consume over 70 and often more than 90 percent of all revenues (Centeno 1997). Weak governments, under attack from within and without, abandoned internal taxes that required an extensive and loyal bureaucracy to collect and concentrated tax collection efforts instead on a few ports and mines. The ratio of tariff revenues to imports, and thus levels of protection, rose in every country for which there are data as did the customs revenues as a percentage of national government revenues.

12 In the words of Bulmer-Thomas (1994: 140), the tariff "was the main source of government income in all [Latin] countries and virtually the only source in a few republics." 
In Brazil the ratio of import duties to imports rose from 15 percent (constrained by the 1810 treaty with Britain) to nearly 30 percent by the 1860s (Leff 1982). That rise was fueled by costly wars with Uruguay (1825-8), Argentina (1851-2), and Paraguay (1865-70) as well as by frequent regional and separatist revolts, slave insurrections, and a massive social and racial upheaval in the Amazon region (Leff 1982; Cleary 1998).

Between 1821 and 1867, Mexico suffered foreign invasions by Spain (1829), the United States (1846-48), and France (1862-67), the secession of Texas (1835), 13 major regional revolts, and at least 60 peasant rebellions and indigenous "caste" wars (Coatsworth 1988). Mexico's first tariff law in 1821 imposed a 25 percent ad valorem tariff on all imports and prohibited only nine items (Potash 1983: 1314). Federalists, who seized power in 1823 , raised rates and multiplied prohibitions. The ratio of tariff duties to imports in liberal Mexico in the 1820 s averaged 36 percent for the decade, then rose to 45 percent under conservative rule in the 1840 s and peaked at 46 percent under liberal rule in the 1870 s and 1880s (Beatty 2001: 53).

Argentine tariff policies followed the Brazil/Mexico trajectory after independence. The first Rivadavia administration lowered tariffs in 1810, but the independence wars (in which Argentine armies invaded Bolivia and Chile) followed by international wars and blockades pushed up rates thereafter. Internal divisions also imposed high costs. Until 1865, the province and city of Buenos Aires functioned as an independent state, frequently at war with one or more of the interior provinces. Despite the dominance of the Buenos Aires elite composed of merchants and export producers, military expenditures forced governments to maximize revenues with high tariffs.

Peru adopted a panoply of non-tariff barriers in addition to raising tariff rates in the immediate aftermath of independence. The colonial legacy of quotas, monopolies, exclusion of foreigners, and other restrictions were not so much an effort to protect producers as to protect merchants in Lima whose loans were often needed to keep the government afloat. Between independence in 1824 and 1841, Peru experienced two episodes of autocratic liberalism associated with the short-lived rule of Simon Bolivar (1823-6) and the equally brief forced integration into the Peru-Bolivia Confederation (1835-39) imposed by an invading Bolivian army commanded by Bolivar's colleague General Andrés Santa Cruz. Despite 
these episodes, however, Peru's frequent civil wars and the parlous state of public finance pushed its rulers toward tariffs as high as the traffic would bear. In contrast with Latin American protectionist persistence up to the belle epoque, however, Peru made a sudden and precocious shift to free trade in 1852 as income from guano exports accelerated, boosting the country's capacity to import dramatically (Gootenberg 1993). This liberalizing influence becomes a more ubiquitous force elsewhere in Latin America after the 1860s, but, as we shall see, it never dominated other offsetting protectionist forces.

In Colombia, with a population barely over a million in 1825 , the death toll from civil conflict between 1820 and 1879 is estimated at nearly 35,000. Internal military conflicts occurred in 163 (22 percent) of the 720 months in these six decades. Colombia initially adopted a "moderate" tariff regime with duties set at their colonial levels of approximately 20 percent. Tariff rates oscillated higher thereafter, rising sharply when trade revenues fell off in 1830-33 and again in 1847, each time followed by modest declines. The "Liberal" Revolution of 1849-52 raised tariff rates twice. McGreevey cited rates of 43 to 110 percent ad valorem on cheap cotton textiles between 1849 and 1905 (McGreevey 1971: 80). But it was not so much high tariff rates as the region's formidable geography that made Colombia's foreign trade sector the smallest in the western hemisphere. McGreevey estimated the ratio of import taxes to imports at only 13.7 percent in the 1850 s, 5.9 percent in $1862-72$, and 11.4 percent in $1873-84$ (McGreevey 1971: 80, 170).

Except for relatively brief wartime episodes, Chile maintained average nominal rates in the 20 to 30 percent range -- modest by Latin American standards -- for most of the $19^{\text {th }}$ century. Tariff rates rose during major wars with Bolivia and Peru (1838-9, 1879-84), but did not reach the extremes common in other countries.

International and internal warfare both appear to have played a major role in pushing the newly independent states toward very high tariffs designed to maximize fiscal revenues. In many cases, local interest groups managed to secure tariff rates (or prohibitions) designed to protect them from external competition, but the benefits from such measures seldom lasted long even in stable Brazil and Chile. The fiscal imperative of the region's endemic military conflicts swamped all other preoccupations. Between 1820 and 1870, most Latin American governments erected enormous tariff barriers that served to protect 
import competing industries, but their political motivation was not protection but rather to keep troops in the field against foreign and domestic enemies.

\section{Optimal Tariffs for Revenue Maximization?}

Were the newly independent Latin American nations searching for some optimal tariff? Were these tariffs really all that the market could bear? Maybe, maybe not, but as Douglas Irwin (1997: pp. 812) has pointed out for the United States case, the revenue-maximizing tariff hinges crucially on the price elasticity of import demand. In the 1850s and 1860s, tariffs fell a bit in Latin America before they started their long run rise to the turn of the century. Bulmer-Thomas (1994: 141) thinks that

These changes were due ... to the growing awareness that a tariff cut could increase revenues if the import price elasticity was greater than one [and as exports] expanded, the volume of imports (the tax base) started to rise sharply in some republics, making possible a cut in the average tariff rate of protection (the tax rate).

Perhaps, but what kind of tariff would have been optimal? Tariff revenue can be expressed as

$$
\mathrm{R}=\mathrm{tpM}
$$

where $\mathrm{R}$ is revenue, $\underline{\mathrm{t}}$ is the average ad valorem tariff rate, $\mathrm{p}$ is the average price of imports and $\mathrm{M}$ is the volume of imports. Totally differentiating (1) with respect to the tariff, and assuming that the typical $19^{\text {th }}$ century Latin American country was a price taker for manufacturing imports, yields

$$
\mathrm{dR} / \mathrm{dt}=\mathrm{pM}+(\mathrm{tp}) \mathrm{dM} / \mathrm{dt}
$$

The revenue-maximizing tariff rate, $\mathrm{t}^{*}$, is found by setting $\mathrm{dR} / \mathrm{dt}=0$, in which case

$$
\mathrm{t}^{*}=-1 /(1+\eta)
$$

where $\eta$ is the price elasticity of demand for imports. Irwin (1997: p. 14) estimates the price elasticity to have been about -2.6 for the US between 1869 and 1913. Since the import mix was similar for the US and 
Latin America, suppose the price elasticity for the latter was about -3 . Under those conditions, the average tariff in Latin America would have been very high indeed, 50 percent. 13

Consider the simple expression (1) again

$$
\mathrm{R}=\mathrm{tpM}
$$

Suppose some Latin America government during the belle epoque - riding on an export boom between the 1870s and World War I -- had in mind some target revenue share in GDP $(\mathrm{R} / \mathrm{Y}=\mathrm{r})$ and could not rely on foreign capital inflows to balance the current account, then

$$
\mathrm{r}=\mathrm{tpM} / \mathrm{Y}=\mathrm{tX} / \mathrm{Y} \text {. }
$$

Clearly, if foreign exchange earnings from exports (and thus imports) were booming (an event which even could be caused by a terms of trade boom, denoted here by a fall in $\mathrm{p}$, the relative price of imports), the target revenue share, $r$, could have been achieved at lower tariff rates, $t$. The bigger the export boom and the higher the resulting export share $(\mathrm{X} / \mathrm{Y})$, the lower the tariff rate.

So, did Latin American governments act as if they were meeting revenue targets? Ceteris paribus, did they lower tariff rates during world primary product booms when export shares were high and rising, and did they raise them during world primary product slumps? Indeed, if they did their tariff-setting perfectly and if they were really committed to target revenue shares, then the elasticity of $\underline{t}$ with respect to $\mathrm{X} / \mathrm{Y}$ would have been -1 .

\section{The Political Economy of Latin American Tariffs: What Else Might Have Mattered?}

\section{The Specific-Duty-Inflation-Deflation Effect}

It has been argued that inflations and deflations have had a powerful influence on average tariff rates in the past. Import duties were typically specific until modern times, ${ }^{14}$ quoted as pesos per bale, yen per yard, or dollars per bag. Under specific duties abrupt changes in price levels would change import

13 We should note that for the ante bellum United States Irwin (2001b) also reports that the optimal export tax would have been about 50 percent at a time when US cotton was King in world markets. In simple trade models, an export tax and an import tariff can be equivalent.

14 They were also specific in $19^{\text {th }}$ century Latin America (Bulmer-Thomas 1994: 141). 
values in the denominator, but not the legislated duty in the numerator, thus producing big equivalent $a d$ valorem or percentage rate changes. Ad valorem rates are more common today, ${ }^{15}$ so that equivalent tariff rates are less affected by inflation and deflation. The impact of inflations during the two world wars were quite spectacular, and they had nothing to do with policy (except status quo ante). Thus, the tariff rates in all four regions fell sharply between 1914 and 1919, and again between 1939 and 1947 (Clemens and Williamson, 2001, Figure 2; Figure 1 above). Part of the rise in tariffs immediately after World War I was also due to post-war deflation and the partial attainment of prewar price levels. The price deflation after 1929 was even more spectacular, and it too served to raise tariff rates at least on duties that were still specific (import values now declining). The process repeats during the World War II inflations, but, in contrast, there is no sign of resumption of the very high rates attained in the 1930s.

The argument assumes, of course, that changing the legislated tariff structure is politically expensive, and thus is only infrequently changed by new legislation. We are certainly not the first to notice this specific-duty-inflation-deflation effect. Douglas Irwin has made the same point in accounting for US tariff experience between the Civil War and the Great Depression where "roughly two-thirds of dutiable U.S. imports were subject to specific or compound duties ...” (Irwin 1998: p. 1017). Although the share fell across the $20^{\text {th }}$ century, it was still half by the mid-1960s. This point has also been made by others (Crucini 1994), but, as far as we know, it has not been explored at a global level nor has an explanation been offered in the literature for its popularity in low-income nations. That is unfortunate since specific duties seem to be much more common in poor and non-industrial countries. Why? The answer might be this: Honest and literate customs inspectors are scarce in poor countries, but honest and literate customs inspectors are needed to implement an ad valorem tariff where import valuation is so crucial. So, legislators impose specific duties to minimize the "theft" of state tariff revenues by dishonest and illiterate customs agents. This explanation for the use of specific duties also suggests that the specificduty-inflation-deflation effect should diminish over time as literate and honest customs inspectors became more abundant in Latin America.

15 A compound duty refers to one that imposes both specific and ad valorem duties on a given import good. 
Although we will insert this specific-duty effect into a more comprehensive explanation of Latin American tariffs in the next section, Table 2 explores its influence by itself. ${ }^{16}$ Whether with country fixed effects or not, the specific-duty effect appears to have been far more important in Latin America after 1913 than before, a surprising result which we will pursue further below. In addition, the specific-duty impact was not more true of inflation-prone regions like Latin America since the effect there was actually smaller than in the US.

\section{Strategic Trade Policy, the Terms of Trade and Tariffs}

A well-developed theoretical literature on strategic trade policy ${ }^{17}$ predicts that nations have an incentive to inflate their own terms of trade (but thereby to lower global welfare) with tariff policy-a classic prisoner's dilemma. In as much as favorable terms of trade translate into better economic performance, we might expect a country's own tariffs to depend at least in part upon the country's external tariff environment. Thus, Figure 5 plots a principal-trading-partners'-tariff index for the same regional clubs. It is calculated like this: first, we identify the major trading partners for each country (up to five); second, we calculate exports going to each major trading partner as a share of total country exports going to all major trading partners; third, we use these shares as weights by which to construct the average tariff faced by each country. Finally, we construct an unweighted average for each region.

Figure 5 tells us that in the two decades before World War I, every region except the industrial core faced lower tariff rates in their main export markets than they themselves erected against competitors in their own markets. The explanation, of course, is that the main export markets were located in the core, where tariffs were much lower. Thus, the periphery faced lower tariffs than did the core (for the European periphery this was true throughout, but for the rest of the periphery it was true only up to just before 1900, when the US replaced Britain as a major export market for them). During the interwar, every club faced

16 The table reports results with and without country fixed effects. Although they are not reported here, the same results emerge with time fixed effects.

17 Exemplified by Dixit (1987) and recently surveyed in Bagwell and Staiger (2000). However, $19^{\text {th }}$ century economic histories of the really big countries are mixed. The US imposed high tariffs (but apparently not quite optimal: James 1981), thus making terms of trade gains, while post-1846 UK imposed low tariffs, thus losing terms of trade gains (Irwin 1988; McCloskey 1980; Williamson 1990). 
very similar and high tariff rates in export markets, but those rates were rising very steeply outside the core as the core itself made the biggest policy switch — compared with the other four clubs - from free trade to protection.

Figure 5 also tells us that Latin America faced far higher tariffs than anyone else since they traded with heavily protected countries like the US. Indeed, if trade with the US is removed from the partner tariff index over the seven decades before the late 1920s, partner tariffs facing Latin American become almost exactly the same as partner tariff's facing the rest of the world. ${ }^{18}$ What the United States was doing with tariff policy must have mattered a great deal to Latin America.

So, did this "hostile" policy environment abroad trigger a like response at home?

\section{The Tariff-Transport Costs Trade Off}

Whatever the arguments for protection, high transport costs on imports from one's trading partner are just as effective as high tariffs. And when transport costs fall dramatically, the winds of competition thus created give powerful incentive to import competing industries to lobby for more protection. Since there was a $19^{\text {th }}$ century transport revolution (O'Rourke and Williamson 1999: Chp. 3), clearly there must have been plenty of incentive for manufacturing interests in the periphery to lobby for protection as the natural barriers afforded by transport costs melted away. This connection was confirmed long ago for the invasion of grains into Europe from Russia and the New World (O’Rourke and Williamson 1999: Chp. 6). But what about Latin America and the "invasion" of European manufactures? There are three reasons to doubt that the tariff-transport costs trade-off prevailed with the same power in Latin America as in Europe. First, while overseas freight rates along the northward routes to Europe from the west and east coast of Latin America followed world trends by collapsing after the 1840s, they fell much less along the southward leg (Stemmer 1989: p. 24). The northward leg was for the bulky Latin American staple exports

18 This conclusion is only based on limited information. We only have partner trade data for the four main trading partners, typically the US, the UK, Germany and some wild card. The wild card is often a Latin American neighbor, and we have ignored trade with the rest, which may also have been a Latin American neighbor. Thus, we can only be sure that Latin America traded with a Core that had very high tariffs, while the rest of the periphery traded with a Core which had low tariffs. Any Latin American's partner tariffs may have been powerfully influenced by tariffs in the region, but we have not measured it. 
- like wheat and guano, the high-volume low-value primary-products whose trade gained so much by the transport revolution. The southward leg was for Latin American imports - like textiles and machines, the high-value low-volume manufactures whose trade gained much less from the transport revolution.

Second, overseas freight costs were a much smaller share of the CIF price of traded manufacturers than was true of traded primary-products. Thus, even under the high transport costs in the 1860 s, freight costs on manufactures (general cargoes) were a very small share of delivered price (Stemmer 1989: p. 25).

Third, transport costs into the Latin American interior were much more important protective barriers for local manufacturers -- except for Buenos Aires, Montevideo and Rio, than were overseas transport costs. Belford Hinton Wilson, a close observer of early-mid 19th century Latin America, reported in 1842 the costs of moving a ton of goods from England to the following capital cities (in pounds sterling): Buenos Aires and Montevideo 2; Lima 5.12; Santiago 6.58; Caracas 7.76; Mexico City 17.9; Quito 21.3; Sucre or Chuquisca, 25.56; and Bogata 52.9 (Brading 1969: pp. 243-4). The variance is huge, with the costs to interior capital cities nine to twenty-seven times that of seaports like Buenos Aires and Montevideo.

Thus, transport revolutions along the sea lanes connecting Latin America to Europe probably had far less to do with tariff responses than did investment in railroads at home. ${ }^{19}$ Where railroads integrated the Latin American interior with the world economy, we should see a protectionist response to the extent that import competing industries were successful in lobbying for protection from these new winds of competition.

\section{The Stolper-Samuelson Theorem and Latin American Capitalists}

Even if the motivation from Latin American tariffs lay with revenues or some other source, they were still protective. And, in contrast with Latin America, even if tariffs in Germany or the United States may have been explicitly adopted to provide protection for domestic producers (Bulmer-Thomas 1994: 140), higher tariffs in Latin American may have been more protective. After all, they served to twist

19 Apparently, Bulmer-Thomas disagrees. While he stresses international transport costs by sea (Bulmer-Thomas 1994: 139), he does not mention railways and the penetration of interior markets. 
relative prices favoring import competing sectors, thus suppressing growth in the export sector and stimulating urban-based manufacturing.

Latin American tariffs in the late $19^{\text {th }}$ century never fell back to pre-independence levels even after the export-led boom filled treasuries with new revenues that reduced debt service to manageable dimensions. Ronald Rogowski (1989) has used the Stolper-Samuelson theorem to suggest that we look to Latin American capitalists for the political economy explanation for those extraordinarily high tariffs during the belle epoque. Though their economies certainly varied in labor-scarcity, every Latin American country faced relative capital scarcity and relative land abundance. As the Stolper-Samuelson theorem has it, "protection benefits (and liberalization of trade harms) owners of factors in which, relative to the rest of the world, that society is poorly endowed" (Rogowski 1989: 3).

According to this kind of thinking, Latin American capitalists should have been looking to form protectionist coalitions as soon as belle epoque peace and growth began to threaten them with freer trade. In most cases, they did not have to look far, either because they managed to dominate oligarchic regimes that excluded other interests, or because they readily found coalition partners willing to help, or both. Growth, peace and political stability after 1870 did not produce democratic inclusion. Most Latin American countries limited the franchise to a small minority of adult men until well into the $20^{\text {th }}$ century. Literacy and wealth requirements, in addition to lack of secrecy in balloting, excluded most potential voters in virtually every country (Engerman and Sokoloff 2001). Non-voters found ways to intrude themselves and their interests into political life, but except for Argentina (after 1912), independent Cuba, post-revolutionary Mexico (after 1917), and Uruguay, restrictions on the adult male franchise did not fall until after 1930.

Growth, peace and political stability in the late $19^{\text {th }}$ century tended to produce oligarchic governments in which urban capitalists -- linked to external trade and finance -- played a dominant role. In countries that specialized in exporting agricultural products, free-trading landowners formed the second dominant part of the governing oligarchy. Free-trading mineral export interests usually had less direct leverage in governmental decision making, despite the size and significance of their investments. Thus, unambiguous protectionist outcomes would hardly have been predicted for all eight countries in our 
sample. In the case of the three mineral exporters (Mexico, Chile, and Peru), mining interests could have allied themselves to powerful regional agricultural interests to lobby against protection. Yet, this did not happen. In the five remaining cases, agricultural exporters held the key to national prosperity and for that reason alone should have found it relatively easy to forge free trade coalitions with other interests. Again, this did not happen. Perhaps one reason why it didn't happen is that free traders might have had their enthusiasm "tempered by the knowledge that government revenue had to be raised somehow, and one obvious alternative to the tariff - a tax on land - was abhorrent to the powerful latifindistas" (BulmerThomas 1994: 140).

The transition from wartime finance and perhaps unintentional protection of domestic industry to deliberate protection of domestic industry occurred in Mexico in the 1890s, a quarter century after the restoration of the Republic in 1867 had ended the last major civil and international war. The economy recovered and grew rapidly, boosted by railroad construction that boomed in the 1880s. Between 1890 and the revolution, average tariff rates soared as the Mexican government adjusted its tariff policies in a deliberate attempt to maintain and even increase effective protection of domestic industries, both those that had long enjoyed protection (like textiles and tobacco) as well as the "nuevas industrias" just starting up (Beatty 2001; Marquez 1998).

The architects of Mexico's new policies of targeted protection for infant industries were a small group of "científicos," educated men whose fortunes originated mainly in foreign trade and real estate, but whose interests had included risky investments in supplying arms and loans to liberal governments and politicians and then branched out into banking, industry, and agriculture. Led by Finance Minister José Yves Limantour, this group acquired considerable autonomy during the last two decades of the presidency of General Porfirio Díaz (1877-80, 1880-1911). For most of that time, Congress routinely ceded power over tariff policy to the executive branch, which increasingly targeted coverage to protect import competing industries. The Mexican government imposed new or increased duties on "wheat, canned beef, bottled and unbottled beer, tobacco, leather and footwear, all woven fiber products, paper, glass bottles, both cement and bricks, caustic sodas, dynamite, soap, crude petroleum, copper bars and sheets, pig iron, iron sheets and plates, steel bars and rods, steel sheets and plates, steel rails, structural 
iron and steel, cut nails, wire, pipes and fittings, and machinery" (Beatty 2001: 59). The beneficiaries of the new protectionism were not numerous. As Haber (1989: 82 and 90) has pointed out, a small clique of "no more than 25" individuals accounted for most of the industrial investment in Mexico during this era. The Mexican Revolution (1910-17) undermined the power and property rights of previously powerful landowners and forced Mexican mining and smelting interests to sell out to foreign, mainly United States companies. In the industrial sector, however, protectionism got a boost from the progressive incorporation of workers' unions into the governing coalition, a process facilitated by government-brokered industry pacts made feasible by corresponding restrictions on imports (Gomez Gavarriato 1998).

Chile's high tariff regime faced few complaints except from northern mining and industrial interests that agitated for even higher tariffs (Zeitlin 1984; Przeworski 1983). Moderately protective tariffs produced revenues for the War of the Pacific (1879-83), but -- as in the pre-1870 decades -- they did not specifically target industrial promotion. Chilean protection advanced notably with the tariff law of 1897 adopted explicitly to promote industry, though rates on imported consumer goods and meat were later reduced. Not until the tariff reforms of 1928, however, did Chile adopt import substituting industrialization as a major policy goal.

In Peru, revenue-creating tariffs were set low in the guano export boom era, especially after 1850 (Bulmer-Thomas 1994: 146), but highland industries, mostly artisan, survived behind high transport costs since railroads took many more decades to reach the main highland cities. Tariffs began to rise after the late 1860 s, then escalated during war with Chile. After the war, Peru's military defeat was compounded by economic and financial collapse. Tariff rates shot up in the 1880 s and 1890 s to compensate for lost revenue and then remained high enough to help foster a substantial industrial take-off.

The standard view is that something much closer to free trade prevailed in agricultural exporting countries where domestic landowners must have dominated politics. Rogowski has argued, for example, that in contrast to the United States, Canada, New Zealand and other "frontier" regions,

In Latin America ... the landowners won: Pushing aside or capturing the military caudillos who had previously dominated postcolonial politics, farmers, ranchers, and miners pursued a liberalism and free trade that maximized their returns from the growing world market in primary 
products. The notoriously weak capitalists of South and Central America, the region's inarticulate and, often, racially oppressed workers, and -- perhaps not least -- the powerful influence of Great Britain as a principal trading partner, all contributed to the political monopoly of the landowning class in this period. Only when trade was interrupted by World War I and the depression of the 1930s... did the suppressed conflict between city and countryside fully manifest itself (Rogowski 1989: 47).

Rogowski appears to have gotten both the politics and tariff policy outcome wrong. Four of the five Latin American agricultural exporters examined here (Argentina, Brazil, Colombia, and Uruguay) expanded export production in the late $19^{\text {th }}$ century by putting new lands to the plough or modernizing and extending pastoral production (cattle and wool) for export. In backward economies with high land-labor ratios, Rogowski argued that expanding trade should produce assertive free trading landed interests pitted against defensive populist alliances of capitalists and workers. In all four of these frontier nations, however, tariff rates were substantially higher than in other world regions. Either Latin America's export producing landowners had less political clout or weaker free trade preferences than this account suggests. Or both.

The political economy of Latin American protectionism between the 1890s and 1930 rested on foundations that favored the protectionist interests of urban capitalists. ${ }^{20}$ That foundation included four building blocks. The first might be labeled weak landed elites. Contrary to much of the historiography of the past century, Latin America's landed elites never resembled the powerful aristocracies in Europe, and, with few but perhaps notable exceptions, they never managed to dominate national politics and economic policymaking. The only landowners that mattered in $19^{\text {th }}$ century Latin America politics were those for whom land represented but one asset in a much broader portfolio (Coatsworth 1988). Small and medium sized properties near towns and cities and more extensive cattle operations further out, along with indigenous or mestizo peasants, dominated most country sides until well into the railroad age. Second, national political power, even in federalist systems, gravitated toward capital cities. Landowners who

20 As well as artisans: "For the artisan sector the tariff had a protective function, and artisans fought hard to retain it" (Bulmer-Thomas 1994: 140). 
wanted national-level clout had to live there or pay others to represent them. Capitalists (merchants, bankers, bond traders, industrialists and their friends, some of whom also owned rural estates) lived in cities and, with independence, exerted disproportionate lobbying influence on policy and politicians. Third, the onset of economic growth and large scale immigration in the 1870 s raised the number and influence of non-elite urban groups, including artisans, middle classes, and eventually workers. These groups were making themselves heard, often violently, by the turn of the century (Collier and Collier 1991); they may have been oppressed, but no Latin American government could afford to ignore or discount them (Skidmore 1978). Finally, workers and their organizations were seldom explicitly protectionist before the 1930s, but they were politically disposable and virtually never allied to landed interests (Collier and Collier 1991).

In short, capitalists secured explicitly protectionist tariffs for existing and new industries beginning in the 1890s. They did so against weak opposition and in close collaboration with modernizing political elites. They did not yet need or even conceive (except in Uruguay, where they followed a particularly effective and visionary national leader) the kind of populist coalitions that emerged in the interwar decades. To maintain and extend industrial protection after World War I and especially after the great depression hit, capitalists would have to acquiesce to extensions of state regulation, control, and ownership - the familiar Leviathan of the ISI era.

\section{The Political Economy of Latin American Tariffs 1870s-1950s: Looking at All Factors in Conjunction}

\section{Empirical Strategy}

Of course, the potential explanations for Latin American protectionism discussed above are not necessarily competing: each may have played a role between independence and the Great Depression. But even if we can show this to be true, we would still like to know which played the biggest roles in accounting for the fact that Latin America was so protectionist for the century before the 1930s. We would also like to know whether things were different before and after World War I. 
What follows in Table 3 is an econometric attack on the problem four ways: first, treating the Latin American eight-country historical experience as an OLS panel 1870-1950; second, treating the experience as comparative Latin American economic history by using country fixed effects (TS); third, by exploring the cross-section variance across these Latin American countries by using time fixed effects (CS); and finally, using fixed effects for both (FE). Although Table 3 presents all four of these regression estimates, we prefer the comparative history (TS) in the second column and the fixed effects (FE) in the last column, primarily because we think the random effects (RE) and OLS results are suspect, and for three reasons. First, RE is best used when we think the estimated effects are based on a randomly drawn sample from a large population. Our Latin American sample is small (eight countries), so randomness is doubtful. Second, RE is typically more efficient and unbiased when the unobserved explanatory variables are uncorrelated with the observed explanatory variables in the regression model. In our case, we think it is likely that the unobserved time and country fixed effects are correlated with the observed right hand side variables in Table 3. For example, country-specific resource endowment would influence GDP as well as tariffs (depending on demand elasticities for the exported resource-based product given that terms of trade or revenues were the targets). Second, econometric tests indicate that the FE results appear to be more efficient and unbiased than the RE results. This is confirmed by the Hausman test, which essentially compares the RE and FE results to see if they are significantly different. The high test statistic reported in Table 3 indicates that they are substantially different, and that the RE results should be discarded.

Having revealed our bias in favor of FE, we must confess that it contains 87 dummy variables, a big number that makes us nervous about efficiency of the FE estimates. With these confessions up front, our expositional strategy will be to focus on the TS in column 2 and the FE results in column 4 of Table 3, but we shall note (the infrequent cases) where the time series (TS) and cross-sections (CS) sharply differ.

The right-hand side variables used throughout are the following (all but dummies in logs):

In (Exports/GDP). This is a measure of export boom, where we expect booms to diminish the need for high tariff rates -- if government revenues are the goal as the qualitative literature suggests -- thus yielding negative coefficients in the regression; 
In (GDP/capita), and In (Primary School Enrollment), the latter a rate. We take both of these variables as proxies for skill endowments, with the expectation that the more abundant the skills, the more competitive the industrial sector, and the less the need for protection, thus yielding a negative coefficient in the regression;

In (Population). Large countries have bigger domestic markets in which it is easier for local firms to find a spatial niche. Thus, the demand for protection should be lower in such countries, and the regression should produce a negative coefficient;

In (Partner Tariffs), measured as a weighted average of the tariff rates in the trading countries' markets, the weight being trade volumes. Strategic tariff policy suggests that Latin American countries should have had higher tariffs if they faced high tariffs in their main markets abroad; In (Effective Distance). The distance from each Latin American country to either the US or the UK (depending on trade volume), that distance adjusted by seaborne freight rates specific to that route. If protection was the goal, effective distance should have been viewed as a substitute for tariffs, so the regression should yield a negative coefficient;

In (km Railways), railway mileage added in kilometers. Poor overland transport connections to interior markets serves as a protective device. Railroads reduce that protection, requiring higher tariffs to offset the effect. Thus, the regression should yield a positive coefficient;

inflation and inflation-squared, the rates in home markets. To the extent that Latin America used specific duties, we expect inflation to lower tariff rates, thus yielding a negative coefficient. However, very rapid inflation might well have triggered a speedier legislative reaction with increases in specific duties, thus yielding a positive and offsetting coefficient on the squared term in the regression;

Federal System, a dummy variable; if a federal system $=1$, if centralized $=0 .{ }^{21}$ Federal governments had a stronger need for customs duties, while centralized governments could better exploit internal revenue sources. Thus, the regression should report a positive coefficient.

21 We reject the federalism values reported in the Polity III data base, and prefer our own. See Appendix xx. 
In (\% pop urban), taken as share of population in cities and towns greater than 20,000 . We take this urbanization statistic to be a proxy for the lobbying power of urban capitalists and artisans, thus yielding a positive coefficient in the regression;

In addition, we experiment with a variable that will be modified in later versions of this paper:

In (UK Pa/Pm). Eventually, this terms of trade variable will measure each country's relative price of primary product exports (compared with manufacturing imports) in world markets. Since the export share variable already includes the combined effect of both price and quantity booms, the terms of trade variable separately isolates the relative cost of manufactured imports as quoted abroad (Britain). Productivity growth achieved by industrial trading partners lowered the relative cost of manufactures in the long run, thus offering a greater threat to import competing industries in Latin America (e.g. inviting de-industrialization), encouraging a protective tariff response. In short, price shocks in world markets that were good for Latin American export sectors were bad for import competing sectors. We expect a positive coefficient on the terms of trade variables in the regression. It is measured here as $\mathrm{Pa} / \mathrm{Pm}$ in Britain, where $\mathrm{Pa}$ and $\mathrm{Pm}$ are indices of agricultural and manufacturing prices, respectively. Both Pa and Pm will be modified in future versions of the paper to make Pa specific to Latin countries (but quoted in British markets).

\section{The Determinants of Latin American Tariffs 1870-1950}

Table 3 suggests that the regression model does quite well in accounting for almost a century of Latin American tariff policy. True, more than half of the variance in the eight-country sample has to be "explained" by the idiosyncratic behavior of each country, but the rest seems to obey some shared laws of political economy motion. Furthermore, the t-statistics on all these variables are typically high enough to pass conventional significance tests. Most importantly, almost everything seems to be of right sign (taken from the TS column in Table 3):

[1] Revenue Goals: Consistent with government revenue motivation, the coefficient on $\ln$ (Exports/GDP) is negative (-0.26) and significant (t-statistic -4.50). Thus, export booms were correlated with lower tariff rates (but perhaps even higher tariff revenues). Symmetrically, export slumps were 
correlated with higher tariff rates (to extract higher tariff revenues). Furthermore, this revenue effect was big, as measured by the beta coefficient ( -0.36 in TS and -0.49 in FE) entered in bold in the row under the t-statistic. ${ }^{22}$ Clearly, revenue goals were one of the most important motivations driving Latin American tariffs to such lofty heights over the eighty years before 1950. Note, however, that the Federal System dummy has the wrong sign in both the TS and FE results. Our expectation was that federalist governments, prior to the interwar rise in the welfare state, would have had more difficulty securing local taxes, and thus would have had to rely more heavily on customs duties. This apparently was not the case since, after controlling for other forces, the coefficient on Federal System is negative in TS (-0.19), not positive, and significant. It is negative again in FE, but barely significant. It is positive, but insignificant, everywhere else.

[2] Market Size and Niches: Big countries, as measured by population size, had lower tariff rates $(-0.64)$, a result consistent with the view that big domestic markets were more friendly to foreign imports since local firms may have found it easier to carve out regional and product niches. Producers in countries with relatively small markets -- in our sample, like Chile, Cuba and Uruguay -- would have found it harder to hide in spatial niches, thus lobbying for higher tariffs. The beta coefficient (-1.50) is the biggest in Table 3.

[3] Inflation and Ad Valorem Duties: Inflation had exactly the predicted effect during an epoch when specific duties were so much more common than ad valorem duties, although, as predicted, very rapid inflation rates apparently triggered faster adjustment. Thus, tariff rates were lower during inflationary episodes, as long as the inflations weren't too spectacular. However, judging by the beta coefficients, this inflation effect had a pretty modest influence on tariffs compared to other forces at work.

[4] Stolper-Samuelson Political Economy: It appears that Stolper-Samuelson forces were indeed operative in Latin America, and Table 3 offers evidence of it in at least two dimensions. The ln (Primary School Enrollment) variable is a proxy for skilled labor endowment, and thus for capacity to compete

22 The beta coefficient is defined as the estimate of the coefficient on the explanatory variable in question multiplied by the ratio of the standard deviation of the underlying explanatory variable to that of the dependent variable. The beta coefficient is one indicator of the relative importance of different regressors; it is the number of standard deviations of the regressand explained by one standard deviation of the regressor. 
with imported foreign manufactures. The coefficient here is negative, supporting the hypothesis: higher skill endowment was associated with lower tariffs in Latin America; however, it is smallest in TS (-0.12), and least significant, being bigger in FE (-0.23) and much more significant. Furthermore, the FE beta coefficient is large (-0.27). The negative coefficient on $\ln (\mathrm{GDP} /$ capita) is consistent with that result: richer countries - who get that way by being more productive and investing more in human and physical capital per capita - have lower tariff rates $(-0.55)$ and the beta coefficient is also very high $(-0.61)$. However, coefficients on $\ln (\%$ pop urban) only offer mixed support for Stolper-Samuelson forces: having relatively scarce capital and skills, and given that these are used primarily in urban activities, urban interests in Latin America should have favored protection. The negative coefficient on ln (\% pop urban) does not support this assertion in TS (-0.44), but we note that it is strongly supported in the CS results $(+0.51)$ and highly significant. What was true in the cross section was not true in the time series, it appears, and we need to learn more about why.

[5] Protectionist Policy: After controlling for everything else, were these Latin American countries acting as if they were protecting local manufacturing? It certainly appears so, and that conclusion is supported consistently by the coefficients on three variables. The variable $\ln$ (Effective Distance) has a negative coefficient (-0.05), although it does not pass conventional significance tests: countries which were protected by higher transport costs along the sea lanes connecting European and local Latin American ports, had lower tariffs. As predicted, the variable ln (km Railways) has a positive coefficient (+0.46): countries with better developed internal railroad networks had higher tariffs, presumably to protect domestic producers from foreign penetration of their internal domestic markets. We also note that the beta coefficient on $\ln$ (km Railways) is much bigger than that on $\ln$ (Effective Distance), fully consistent with our predictions. Finally, as we shall see below in a moment, the terms of trade in world markets had an effect consistent with the other two measures of protectionist response. The combined effect of these three variables suggests that high Latin American tariffs were indeed driven by protectionist goals.

[6] Strategic Tariff Policy: These eight Latin American economies also seem to reveal strategic tariff policy behavior to the extent that the coefficient on $\ln$ (Partner Tariffs) is positive $(+0.19)$ and 
significant: countries trading with high tariff partners (mainly the United States) adopted high tariffs themselves; countries trading with low tariff partners (mainly the United Kingdom) adopted low tariffs themselves. However, the effect does not appear in CS or FE, and the beta coefficient in TS $(+0.17)$ suggests that it was not an important determinant of Latin American tariff policy.

[7] Additional Variables: Table 4 adds three additional variables to the basic model just discussed. We think all three have great promise and will get more attention in a future version of this paper, but their documentation here is limited. First, there is $\ln (\mathrm{UK} \mathrm{Pa} / \mathrm{Pm})$. As we pointed out above, this is a crude index of the relative price of manufactures in world (e.g. British) markets, where Pm is a price index of manufactures and $\mathrm{Pa}$ is a price index of primary products. When the relative price of manufactures fell in world markets - reflecting relatively fast productivity advance in European industry, the threat of an invasion of manufactures triggered a powerful protectionist response in Latin America $(+0.44$ in the TS). However, in its present version this relative price index is the same for all countries in any given year. We intend in future versions of this paper to make Pa specific to each of our eight Latin American countries and its export products (although still quoted in British markets). ${ }^{23}$ Second, Latin America countries which were successful in getting external finance would have had less reason to use high tariffs to augment revenues. Table 4 explores this idea using the Stone data on British capital exports before World War I (Clemens and Williamson 2000). While these data do not cover all sources of capital nor all years, we do note the negative coefficient on the variable in Table 4: more foreign capital was associated with lower tariffs. Third, we add an energy consumption variable (when available for the post World War I years) to index the size of the manufacturing sector. While the coefficient is negative $(-0.55)$ and highly significant, we are not sure about interpretation. Is it that a large manufacturing sector marks countries who can and do compete effectively with foreign imports and thus have less need for tariffs?

23 The independent contribution of an export price boom to tariff behavior is already captured in the Exports/GDP variable. 


\section{Were the Determinants of Tariffs Different after the Belle Epoque?}

Table 5 reports an attempt to test the null hypothesis that the years after belle epoque were the same as those before, at least in the way that tariffs were determined. The third column under each of the four estimation procedures, "All”, covers the full 1870-1950 period, and it repeats Table 3. The other two columns report the estimation for the period up to 1913 (the belle epoque) and after 1914. The comparison is not without problems, since the data base for the earlier period is probably not as good, indeed, missing many country-year observations. Nonetheless, we predict the tariff levels for both periods, and then perform a T-test to see if the means are the same in the two periods. The T-test is performed three times: 1870-1913 vs 1870-1950 -- e.g., was the belle epoque the same as the full period?; 1914-1950 vs 1870-1950 - e.g. was the post-belle epoque the same as the full period?: and 1870-1913 vs 1914-1950 - e.g. were the belle epoque and the post- belle epoque the same? In all twelve cases but one, we can reject the null hypothesis that the predicted levels are the same.

So, not only were tariffs very high in the belle epoque, but the determinants of tariff policy were different then too. How were they different? Consider the time series results in Table 5 (country dummies $=$ country fixed effects). Some of the tariff determinants remain unchanged on either side of 1913, like GDP per capita, effective distance, and inflation. But most did change. Consider four. First, the revenue effect as measured by $\ln ($ Exports/GDP) was much more powerful after 1913 then during the belle epoque. This comes as a surprise given the contrary accounts in the qualitative literature. Second, strategic tariff policy as reflected by $\ln$ (Partner Tariffs) was not only more powerful after 1913, but was not present at all in the belle epoque. The rise of strategic tariff policy in Latin America during the years when the global economy was disintegrating is consistent with results reported by Clemens and Williamson (2001) on the world economy and the qualitative literature. Third, in the de-globalized war and interwar years, the response of (less) protection to increasing domestic economy size in Latin American (population) became much bigger. Fourth, the positive response of protection to foreign penetration of interior markets $(\mathrm{km}$ railways) was much bigger in the belle epoque than after 1913, perhaps because the main impact of the railways on spatial market integration was nearly complete by World War I. 


\section{Concluding Remarks and an Agenda on Historical Persistence}

This paper started by uncovering a fact that has not been well appreciated. Tariffs in Latin America were far higher than anywhere else in the world from the 1860s to World War I, long before the Great Depression. Indeed, tariff rates in Latin America were even on the rise in the decades before 1914, a period that has been called the first globalization boom for the world economy and the belle epoque for Latin America. To repeat, this fact is surprising for three reason. First, it comes as a surprise given that this region has been said to have exploited globalization forces better than most during the pre-1914 belle epoque. Second, it comes as a surprise since standard economic histories say so little about it. Third, it comes as a surprise to most of us who have always been taught to view the Great Depression as the critical turning point when the region is said to have turned towards protection and de-linked from the world economy for the first time.

The paper shows that the explanation of the fact cannot lie with some perceived GDP per capita gains from protection, since such gains were never present in Latin America. On the contrary, those who had the highest tariff rates in Latin America grew the slowest, and those who had the lowest tariff rates grew fastest. The paper then goes on to explore the motivation for Latin American tariffs as a revenue source, as a protective device for special interests, and as a consequence of other political economy struggles. The exploration from 1820 to 1950 is successful, and we are able to identify the importance of revenue goals, the role of domestic market size and isolated-from-foreign-competition niches, inflation

and specific duty effects, Stolper-Samuelson forces political economy forces, explicit protectionist policy, and strategic tariff policy in response to that of (far bigger and richer) trading partners. While the exploration is mostly qualitative for the first half century of independence, it is quite quantitative for the period 1870-1950, using annual data for a sample of eight Latin American countries treated both as a panel and with country fixed effects.

While the paper concludes by showing exactly how belle epoque tariff determination differed from the period after 1913, the paper is not able to report whether the same pro-protection conditions exist 
today as those which existed more than a century ago. Surely, that's the next item on any agenda that intends to explore the political economy of protection in Latin America.. 


\section{References}

J. E. Anderson (1998), “Trade Restrictiveness Benchmarks,” Economic Journal 108 (July): 1111-25.

J. E. Anderson and J. P. Neary (1994), "Measuring the Restrictiveness of Trade Policy," The World Bank Economic Review 8 (May): 151-69.

K. Bagwell and R. W. Staiger (2000), “GATT-Think," NBER Working Paper 8005, National Bureau of Economic Research, Cambridge, Mass. (xxxx).

S. L. Baier and J. H. Bergstrand (2001), "The Growth of World Trade: Tariffs, Transport Costs, and Income Similarity," Journal of International Economics 53, 1: 1-27.

P. Bairoch 1972. "Free Trade and European Economic Development in the $19^{\text {th }}$ Century," European Economic Review 3 (November): 211-45.

--- (1989), "European Trade Policy, 1815-1914," in The Cambridge Economic History of Europe, vol. III, ed. by P. Mathias and S. Pollard (Cambridge: Cambridge University Press).

R. E. Baldwin (1969), “The Case Against Infant-Industry Tariff Protection,” Journal of Political Economy 77 (May/June): 295-305.

E. Beatty (2001), Institutions and Investment: The Political Basis of Industrialization Before 1911 (Stanford: Stanford University Press).

J. Bhagwati and A. O. Krueger, eds. (1973-1976), Foreign Trade Regimes and Economic Development, multiple volumes with varying authorship (New York: Columbia University Press).

D. E. Bloom and J. G. Williamson (1998), “Demographic Transitions and Economic Miracles in Emerging Asia," World Bank Economic Review 12 (September): 419-55.

C. W. Brading (1969), "Un analisis comparativo del costo de la vida en diversas capitales de hispanoamerica," Boletin Historico de la Fundacion John Boulton 20 (March 1969): 229-63.

V. Bulmer-Thomas (1994), The Economic History of Latin America Since Independence (Cambridge: Cambridge University Press).

F. Capie (1983), "Tariff Protection and Economic Performance in the Nineteenth Century," in J. Black and L. A. Winters (eds.), Policy and Performance in International Trade (London: Macmillan). 
M. A. Centeno (1997), "Blood and Debt: War and Taxation in Nineteenth-Century Latin America," American Journal of Sociology 102 (May): 1565-605.

D. Cleary (1998), "'Lost Altogether to the Civilized World': Race and the Cabanagem in Northern Brazil, 1750-1850," Comparative Studies in Society and History 401 (January): 109-35.

M. A. Clemens and J. G. Williamson (2000), "Where Did British Foreign Capital Go? Policies, Fundamentals and the Lucas Paradox 1870-1913," NBER Working Paper 8028, National Bureau of Economic Research, Cambridge, Mass. (December).

--- (2001), “A Tariff-Growth Paradox? Protection’s Impact the World Around 1875-1997,” NBER Working Paper 8459, National Bureau of Economic Research, Cambridge, Mass. (September).

— (2002), "Who Protected and Why? Tariffs the World Around 1865-1940" (forthcoming).

J. H. Coatsworth (1988), "Patterns of Rural Rebellion in Latin America: Mexico in Comparative Perspective" in Riot, Rebellion, and Revolution: Rural Social Conflict in Mexico ed. by F. Katz (Princeton: Princeton University Press), pp. 21-62.

D. Collier and R. B. Collier (1991), Shaping the Political Arena: Critical Junctures, the Labor Movement, and Regime Dynamics in Latin America (Princeton: Princeton University Press).

V. Corbo (1992), "Development Strategies and Policies in Latin America: A Historical Perspective," International Center for Economic Growth, Occasional Paper No. 22 (April): 16-48.

M. J. Crucini (1994), "Sources of Variation in Real Tariff Rates: The United States 1900-1940,” American Economic Review 84 (June): 732-43.

C. Diaz-Alejandro (1984), "Latin America in the 1930s," in R. Thorp (ed.), Latin America in the 1930s (New York: Macmillan): 17-49.

A. Dixit (1987), "Strategic Aspects of Trade Policy," in T. F. Bewley (ed.), Advances in Economic Theory: Fifth World Congress (New York: Cambridge University Press).

D. Dollar (1992), “Outward-Oriented Developing Economies Really Do Grow More Rapidly: Evidence from 95 LDCs, 1976-1985," Economic Development and Cultural Change 40 (April): 523-44. D. Dollar and A. Kraay (2000), “Trade, Growth, and Poverty.” Manuscript, World Bank (October). 
P. W. Drake (1989), The Money Doctor in the Andes: The Kemmerer Missions 1923-1933 (Durham, NC: Duke University Press).

A. Eckes (1995), Opening America's Market: U.S. Foreign Trade since 1776 (Chapel Hill: University of North Carolina Press).

S. Edwards (1993), “Openness, Trade Liberalization, and Growth in Developing Countries,” Journal of Economic Literature 31 (September): 1358-94.

S. Engerman and K. Sokoloff (2001), "The Evolution of Suffrage in the New World: A Preliminary Examination," paper presented to the 2001 Cliometrics Conference, Tuscon, Arizona (May 1820).

P. K. Goldberg and G. Maggi (1999), "Protection for Sale: An Empirical Investigation,” American Economic Review 89, 5 (December): 1135-55.

A. Gomez-Galvarriato (1998), "The Evolution of Prices and Real Wages in Mexico from the Porfiriato to the Revolution," in J. H. Coatsworth and A. M. Taylor, eds. Latin America and the World Economy Since 1800 (Cambridge: Harvard University Press), pp. 347-78.

P. Gootenberg (1993), Imagining Development: Economic Ideas in Peru's Fictitious Prosperity of Guano, 1840-1880 (Berkeley: University of California Press).

G. Grossman and E. Helpman (1994), "Protection for Sale," American Economic Review 84 (September): $833-50$.

S. H. Haber (1989), Industry and Underdevelopment: The Industrialization of Mexico,1890-1940 (Stanford, Calif.: Stanford University Press).

D. A. Irwin (1988), "Welfare Effects of British Free Trade: Debate and Evidence from the 1840s," Journal of Political Economy 96 (December): 1142-64.

— (1997), "Higher Tariffs, Lower Revenues? Analyzing the Fiscal Aspects of the Great Tariff Debate of 1888," NBER Working Paper 6239, National Bureau of Economic Research, Cambridge, Mass. (October).

--- (1998), “Changes in U.S. Tariffs: The Role of Import Prices and Commercial Policies?” American Economic Review 88 (September): 1015-26. 
— (2001a), "Tariffs and Growth in Late Nineteenth Century America,” World Economy 24 (January):1530.

— (2001b), “The Optimal Tax on Antebellum U.S. Cotton Exports,” NBER Working Paper 8689, National Bureau of Economic Research, Cambridge, Mass. (December).

J. A. James (1981), "The Optimal Tariff in the Antebellum United States," American Economic Review 71(4): 726-34.

C. P. Kindleberger (1951), "Group Behavior and International Trade," Journal of Political Economy 59 (February): 30-46.

A. O. Krueger (1983), “The Effects of Trade Strategies on Growth,” Finance and Development 20 (June): 6-8.

--- (1984), “Trade Policies in Developing Countries,” in R. Jones and P. Kenan (eds.), Handbook of International Economics, volume 1. Amsterdam: North-Holland.

N. H. Leff (1982), Underdevelopment and Development in Brazil: vol. 1, Economic Structure and Change, 1822-1947 and vol. 2, Reassessing the Obstacles to Economic Underdevelopment (London: George Allen and Unwin).

P. H. Lindert and J. G. Williamson (2001), “Does Globalization Make the World More Unequal?” NBER Working Paper 8228, National Bureau of Economic Research, Cambridge, Mass. (April).

S. P. Magee, W. A. Brock and L. Young (1989), Black Hole Tariffs and Endogenous Policy Theory (Cambridge: Cambridge University Press).

S. P. Magee and L. Young (1987), "Endogenous Protection in the United States, 1900-1984," in R. M. Stern (ed.), U.S. Trade Policies in a Changing World Economy (Cambridge, Mass.: MIT Press).

D. Mares (2001), Violent Peace: Militarized Interstate Bargaining In Latin America (New York. Columbia University Press).

G. Márquez (1998), “Tariff Protection in México, 1892-1909: Ad Valorem Tariff Rates and Sources of Variation," in J. H. Coatsworth and A. M. Taylor, eds. Latin America and the World Economy Since 1800 (Cambridge: Harvard University Press), pp. 407-42. 
D. N. McCloskey (1980), "Magnanimous Albion: Free Trade and British National Income, 1841-1881," Explorations in Economic History 17 (July): 303- 20.

W. P. McGreevey (1971), An Economic History of Colombia, 1845-1930 (Cambridge: Cambridge University Press).

K. H. O'Rourke (2000), “Tariffs and Growth in the Late $19^{\text {th }}$ Century,” Economic Journal 110 (April): 456-83.

K. H. O’Rourke and J. G. Williamson (1999), Globalization and History (Cambridge, Mass.: MIT Press).

--- (2002), “After Columbus: Explaining the European Overseas Trade Boom 1500-1800,” Journal of Economic History 62 (June): 1-40.

R. A. Potash (1983), Mexican Government and Industrial Development in the Early Republic: The Banco de Avío (Amherst: University of Massachusetts Press).

L. Pritchett (1997), “Divergence, Big Time,” Journal of Economic Perspectives 11 (Summer): 3-18.

J. F. Przeworski (1980), The Decline of the Copper Industry in Chile and the Entrance of North American Capital, 1870-1916 (New York: Arno Press).

F. Rodriguez and D. Rodrik (1999), “Trade Policy and Economic Growth: A Skeptic's Guide to the Cross-National Evidence," NBER Working Paper 7081, National Bureau of Economic Research (April).

R. Rogowski (1989), Commerce and Coalitions: How Trade Affects Domestic Political Alignments (Princeton, NJ: Princeton University Press).

J. D. Sachs and A. Warner (1995), "Economic Reform and the Process of Global Integration," Brookings Papers on Economic Activity, I (Washington, D.C.: Brookings Institution).

T. Skidmore (1978), “A Case of Conspicuous Neglect? The Study of Urban Labor Movements and Elite Responses in Latin America.” Unpublished paper.

J. Stemmer (1989), "Freight Rates in the Trade between Europe and South America," Journal of Latin American Studies 21, pt. 1 (February): 22-59.

A. Taylor (1998), “On the Costs of Inward-Looking Development: Price Distortions, Growth, and Divergence in Latin America," Journal of Economic History 58 (March): 1-28. 
A. Vamvakidis (1997), "How Robust Is the Growth-Openness Connection? Historical Evidence," mimeo. Cambridge, Mass.: Harvard University.

J. G. Williamson (1990), "The Impact of the Corn Laws Just Prior to Repeal," Explorations in Economic History 27 (April): 123-56.

--- (1998), "Globalization, Labor Markets and Policy Backlash in the Past,” Journal of Economic Perspectives 12 (Fall): 51-72.

M. Zeitlin (1984), The Civil Wars in Chile, or, The bourgeois Revolutions that Never Were (Princeton, N.J.: Princeton University Press). 


\section{Table 1:}

\section{Tariff Impact on GDP per capita Growth by Region}

Dependent Variable: $\quad$ 5-Year Overlapping Average Growth Rate

(1)

Included Countries
Years per Period
Time Interval
(2)

(3)
(4)

\begin{tabular}{|c|c|c|c|}
\hline $\begin{array}{r}\text { ALL } \\
1 \\
1875-1908\end{array}$ & $\begin{array}{r}\text { ALL } \\
1 \\
1875-1908\end{array}$ & $\begin{array}{r}\text { ALL } \\
1 \\
1924-1934\end{array}$ & $\begin{array}{r}\text { ALL } \\
1 \\
1924-1934\end{array}$ \\
\hline $\begin{array}{l}0.15 \\
1.14\end{array}$ & $\begin{array}{l}0.10 \\
0.75\end{array}$ & $\begin{array}{l}-0.73 \\
-1.77\end{array}$ & $\begin{array}{l}-0.89 \\
-2.13\end{array}$ \\
\hline $\begin{array}{l}0.14 \\
1.64\end{array}$ & $\begin{array}{l}0.56 \\
3.35\end{array}$ & $\begin{array}{l}0.36 \\
1.27\end{array}$ & $\begin{array}{l}1.65 \\
2.83\end{array}$ \\
\hline & $\begin{array}{l}-0.72 \\
-3.32\end{array}$ & & $\begin{array}{l}-2.45 \\
-3.18\end{array}$ \\
\hline & $\begin{array}{l}-0.97 \\
-3.15\end{array}$ & & $\begin{array}{l}0.58 \\
0.49\end{array}$ \\
\hline & $\begin{array}{l}-0.19 \\
-0.84\end{array}$ & & $\begin{array}{l}-1.47 \\
-2.02\end{array}$ \\
\hline $\begin{array}{l}-0.21 \\
-1.24\end{array}$ & $\begin{array}{l}1.58 \\
2.77\end{array}$ & $\begin{array}{l}-0.04 \\
-0.08\end{array}$ & $\begin{array}{l}6.15 \\
3.10\end{array}$ \\
\hline $\begin{array}{l}0.19 \\
0.94\end{array}$ & $\begin{array}{l}3.01 \\
3.13\end{array}$ & $\begin{array}{l}-0.73 \\
-1.31\end{array}$ & $\begin{array}{l}-3.31 \\
-0.96\end{array}$ \\
\hline $\begin{array}{l}-0.26 \\
-1.09\end{array}$ & $\begin{array}{l}0.30 \\
0.55\end{array}$ & $\begin{array}{l}-1.17 \\
-1.52\end{array}$ & $\begin{array}{l}2.39 \\
1.24\end{array}$ \\
\hline $\begin{array}{l}-0.12 \\
-0.11\end{array}$ & $\begin{array}{l}-0.76 \\
-0.68\end{array}$ & $\begin{array}{l}5.92 \\
1.55\end{array}$ & $\begin{array}{l}3.99 \\
1.05\end{array}$ \\
\hline $\begin{array}{l}\text { No } \\
\text { No }\end{array}$ & $\begin{array}{l}\text { No } \\
\text { No }\end{array}$ & $\begin{array}{l}\text { No } \\
\text { No }\end{array}$ & $\begin{array}{l}\text { No } \\
\text { No }\end{array}$ \\
\hline $\begin{array}{r}1,190 \\
0.0357 \\
0.0317\end{array}$ & $\begin{array}{r}1,190 \\
0.0498 \\
0.0433\end{array}$ & $\begin{array}{r}372 \\
0.0227 \\
0.0094\end{array}$ & $\begin{array}{r}372 \\
0.0605 \\
0.0398\end{array}$ \\
\hline
\end{tabular}

Country Dummies?

Time Dummies?

$\mathrm{N}$

R-squared

Adj. R-squared
(Asia dummy) $\mathrm{x}$

(In tariff rate)

Euro Periph dummy

Latin America dummy

Asia dummy

Constant
$-0.12$

$-0.11$
$-0.76$

1.55

\subsection{9}

$t$-statistics are in italics 
Table 2:

Inflation's Impact on Tariffs in Latin America and the US, 1870-1950

Dependent Variable: Growth Rate

(1)

(2)

(3)

Lat Am (8) Lat Am (8) Lat Am (8) Lat Am (8) $\begin{array}{rrrr}1 & 1 & 1 & 1 \\ 1870-1913 & 1870-1913 & 1914-1929 & 1914-1929\end{array}$

Time Interval

Inflation

Constant

Country dummies?

Time dummies?

R-squ

Adj R-squ

\# of obs

$t$-statistics are in italics

\begin{tabular}{rrrrrrrr}
\hline-0.02 & -0.02 & -0.16 & -0.11 & -0.35 & -0.47 & -0.12 & -0.12 \\
-0.45 & -0.69 & -2.30 & -2.18 & -3.37 & -5.30 & -3.55 & -4.09 \\
& & & & & & & \\
0.0004 & 0.0002 & 0.0040 & 0.0025 & 0.0063 & 0.0069 & 0.0008 & 0.0007 \\
2.54 & 1.94 & 1.96 & 1.55 & 1.93 & 2.50 & 5.61 & 5.17 \\
& & & & & & & \\
28.70 & 25.22 & 19.62 & 13.59 & 21.18 & 18.06 & 24.75 & 20.95 \\
48.05 & 24.01 & 26.98 & 11.32 & 25.58 & 11.16 & 55.37 & 20.65 \\
& & & & & & & No \\
No & Yes & No & Yes & No & Yes & Yes \\
No & No & No & No & No & No & No & No \\
& & & & & & & \\
0.0510 & 0.5723 & 0.0530 & 0.5843 & 0.0737 & 0.3925 & 0.0549 & 0.2712 \\
0.0446 & 0.5591 & 0.0346 & 0.5453 & 0.0624 & 0.3577 & 0.0516 & 0.2596 \\
302 & 302 & 106 & 106 & 167 & 167 & 575 & 575
\end{tabular}

\begin{tabular}{rrrr} 
(9) & \multicolumn{1}{c}{$(10)$} & \multicolumn{1}{l}{$(11)$} & \multicolumn{1}{l}{$(12)$} \\
USA & USA & USA & USA \\
1 & 1 & 1 & 1 \\
$1870-1913$ & $1914-1929$ & $1930-1950$ & $1870-1950$ \\
& & & \\
-0.67 & -0.11 & -0.39 & -0.44 \\
-2.70 & -0.95 & -2.29 & -2.04 \\
& & & \\
0.0903 & -0.0148 & 0.0107 & -0.0260 \\
1.50 & -2.00 & 0.74 & -1.62 \\
& & & \\
26.84 & 13.18 & 13.29 & 22.07 \\
28.08 & 20.22 & 12.30 & 22.22 \\
& & & \\
\hline & & & \\
No & No & No & No \\
No & No & No & No \\
& & & \\
0.1834 & 0.6458 & 0.2318 & 0.1957 \\
0.1436 & 0.5913 & 0.1464 & 0.1751 \\
44 & 16 & 21 & 81
\end{tabular}


Table 3

Comparative Regressions of Endogenous Tariff Determinants, 1870-1950

Dependent Variable:

In (Own Tariff)

In (Exports/GDP)

$\frac{(1)}{\text { OLS }}$

\begin{tabular}{c}
$(2)$ \\
\hline TS
\end{tabular}

\begin{tabular}{ccc}
$\frac{(3)}{C S}$ & & \multicolumn{1}{l}{$(4)$} \\
-0.32 & & -0.35 \\
-6.18 & & -5.72 \\
$-\mathbf{0 . 4 4}$ & & $-\mathbf{0 . 4 9}$
\end{tabular}

In (GDP/capita)

$-0.29$

$-6.13$

$-0.26$

-4.50
-0.36

$-0.44$

$-0.49$

$-0.39$

$-0.55$

$-0.30$

$-0.54$

$-5.48$

$-5.18$

$-3.67$

$-4.60$

$-0.44$

$-0.61$

$-0.34$

$-0.60$

In (Population)

$-0.35$

$-0.64$

$-0.01$

$-0.58$

$-7.44$

$-6.58$

$-0.13$

$-3.77$

$-0.81$

$-1.50$

$-0.02$

$-1.35$

In (Partner Tariffs)

0.15

0.19

3.75

0.01

$-0.09$

$0.14-1.32$

0.14

0.17

0.01

$-0.08$

In (Effective Distance)

$-0.09$

$-3.18$

$-0.05$

$-1.67$

$-0.03$

$-0.67$

$-0.03$

$-0.05$

In (km Railways)

0.14

4.21

0.46

$-0.10$

$-0.05$

0.44

9.22

$-2.25$

0.01

$-0.290 .10$

Inflation

$-0.005$

$-3.57$

$-0.003$

$-0.002$

0.03

$-1.64 \quad-0.99$

$-0.16-0.09$

Inflation-squared

0.00005

3.82

0.00002

1.61

$-0.04$

0.17

0.06

0.00003

0.00001

$2.36 \quad 1.18$

In (Primary School

$-0.37$

$-4.75$

$-0.12$

$-1.51$

$-0.14$

$-0.25$

$-3.12$

0.05

Enrollment)

$-0.44$

$-0.19$

$-2.88$

$-0.19$

$-0.23$

$-2.62$

$-0.30 \quad-0.27$

Federal System

1.15

0.06

0.01

0.23

$-0.12$

$-1.83$

$0.01-0.12$

In (\% pop'n urban)

0.24

3.75

$-0.44$

$-4.36$

$-0.61$

0.51

7.37

$-0.04$

$-0.29$

$0.70-0.05$

Constant

9.12

11.88

4.66

13.10

Country $(\mathrm{n}=8)$ Dummies?

Year $(t=81)$ Dummies

\begin{tabular}{rrrr}
\hline No & Yes & No & Yes \\
No & No & Yes & Yes \\
& & & \\
0.4035 & 0.5574 & 0.6371 & 0.6909 \\
0.3878 & 0.538 & 0.5445 & 0.6039 \\
429 & 429 & 429 & 429 \\
& $\underline{\mathrm{n}}$ & $\underline{\mathrm{t}}$ & $\underline{\mathrm{n} / \mathrm{t}}$ \\
& 38.2 & 12.01 & 8.13 \\
& 20.38 & 2.89 & $8.30 / 1.90$ \\
& 8 & 77 & $8 / 77$ \\
& 53.6 & 5.6 & $53.6 / 5.6$ \\
& 199.08 & 154.74 & $59.8 / 199.6$
\end{tabular}

$t$-statistics are in italics

beta values are in bold 
Table 4

Endogenous Tariffs: Adding Three (Poorly-Documented) Variables with Promise

Dependent Variable:

In (Own Tariff)

\begin{tabular}{|c|c|c|c|c|c|c|c|c|c|c|c|c|}
\hline \multirow[b]{4}{*}{ In (Exports/GDP) } & (1) & (2) & (3) & \multirow[t]{2}{*}{ (4) } & \multirow{2}{*}{\multicolumn{4}{|c|}{$\begin{array}{lll}\text { (6) } & (7) \\
& \mathbf{1 9 1 9 - 1 9 5 0} \\
\end{array}$}} & \multirow{2}{*}{\multicolumn{4}{|c|}{ (10) $\quad(11)$}} \\
\hline & \multirow{2}{*}{\multicolumn{4}{|c|}{\begin{tabular}{|ll}
$1870-1914$ & \\
& Time Series \\
\end{tabular}}} & & & & & & & & \\
\hline & & & & & \multicolumn{2}{|c|}{ OLS } & \multicolumn{2}{|c|}{ Time Series } & \multicolumn{2}{|c|}{ OLS } & \multicolumn{2}{|c|}{ Time Series } \\
\hline & $\begin{array}{l}-0.07 \\
-1.10\end{array}$ & $\begin{array}{l}-0.04 \\
-0.63\end{array}$ & $\begin{array}{l}-0.07 \\
-1.00\end{array}$ & $\begin{array}{l}-0.07 \\
-0.97\end{array}$ & $\begin{array}{l}-0.62 \\
-9.09\end{array}$ & $\begin{array}{l}-0.55 \\
-8.28\end{array}$ & $\begin{array}{l}-0.51 \\
-5.55\end{array}$ & $\begin{array}{l}-0.47 \\
-5.28\end{array}$ & $\begin{array}{l}-0.16 \\
-3.49\end{array}$ & $\begin{array}{l}-0.17 \\
-3.90\end{array}$ & $\begin{array}{l}-0.16 \\
-3.08\end{array}$ & $\begin{array}{l}-0.19 \\
-3.53\end{array}$ \\
\hline In (GDP/capita) & $\begin{array}{l}0.27 \\
2.20\end{array}$ & $\begin{array}{l}0.31 \\
2.56\end{array}$ & $\begin{array}{l}-0.46 \\
-2.21\end{array}$ & $\begin{array}{l}-0.46 \\
-2.18\end{array}$ & $\begin{array}{l}-0.76 \\
-8.14\end{array}$ & $\begin{array}{l}-0.60 \\
-6.44\end{array}$ & $\begin{array}{l}-0.53 \\
-2.29\end{array}$ & $\begin{array}{l}-0.03 \\
-0.12\end{array}$ & $\begin{array}{l}-0.03 \\
-0.47\end{array}$ & $\begin{array}{r}0.00 \\
-0.05\end{array}$ & $\begin{array}{l}-0.41 \\
-3.96\end{array}$ & $\begin{array}{l}-0.43 \\
-4.15\end{array}$ \\
\hline In (Population) & $\begin{array}{l}0.19 \\
2.73\end{array}$ & $\begin{array}{l}0.25 \\
3.52\end{array}$ & $\begin{array}{l}-0.30 \\
-1.32\end{array}$ & $\begin{array}{l}-0.27 \\
-1.17\end{array}$ & $\begin{array}{l}-0.70 \\
-7.85\end{array}$ & $\begin{array}{l}-0.83 \\
-9.41\end{array}$ & $\begin{array}{l}-0.86 \\
-2.87\end{array}$ & $\begin{array}{l}-0.50 \\
-1.69\end{array}$ & $\begin{array}{l}-0.01 \\
-0.24\end{array}$ & $\begin{array}{l}0.08 \\
1.61\end{array}$ & $\begin{array}{l}-0.30 \\
-3.09\end{array}$ & $\begin{array}{r}-0.20 \\
-1.80\end{array}$ \\
\hline In (Partner Tariffs) & $\begin{array}{l}0.24 \\
3.25\end{array}$ & $\begin{array}{l}0.23 \\
3.18\end{array}$ & $\begin{array}{l}-0.06 \\
-0.75\end{array}$ & $\begin{array}{l}-0.06 \\
-0.75\end{array}$ & $\begin{array}{l}0.17 \\
2.39\end{array}$ & $\begin{array}{l}0.10 \\
1.42\end{array}$ & $\begin{array}{l}0.23 \\
2.74\end{array}$ & $\begin{array}{l}0.17 \\
2.11\end{array}$ & $\begin{array}{l}0.19 \\
3.91\end{array}$ & $\begin{array}{l}0.24 \\
4.90\end{array}$ & $\begin{array}{l}0.24 \\
4.76\end{array}$ & $\begin{array}{l}0.25 \\
4.98\end{array}$ \\
\hline In (Effective Distance) & $\begin{array}{l}-0.06 \\
-1.14\end{array}$ & $\begin{array}{l}-0.06 \\
-1.22\end{array}$ & $\begin{array}{l}-0.03 \\
-0.55\end{array}$ & $\begin{array}{l}-0.03 \\
-0.63\end{array}$ & $\begin{array}{l}-0.08 \\
-2.09\end{array}$ & $\begin{array}{l}-0.11 \\
-2.83\end{array}$ & $\begin{array}{l}-0.06 \\
-1.31\end{array}$ & $\begin{array}{l}-0.07 \\
-1.76\end{array}$ & $\begin{array}{l}-0.09 \\
-3.19\end{array}$ & $\begin{array}{l}-0.08 \\
-2.64\end{array}$ & $\begin{array}{l}-0.07 \\
-2.21\end{array}$ & $\begin{array}{l}-0.08 \\
-2.30\end{array}$ \\
\hline In (km Railways) & $\begin{array}{l}-0.12 \\
-2.75\end{array}$ & $\begin{array}{l}-0.13 \\
-3.09\end{array}$ & $\begin{array}{l}0.41 \\
5.70\end{array}$ & $\begin{array}{l}0.40 \\
5.40\end{array}$ & $\begin{array}{l}0.34 \\
5.16\end{array}$ & $\begin{array}{l}0.50 \\
7.15\end{array}$ & $\begin{array}{l}0.55 \\
1.99\end{array}$ & $\begin{array}{l}0.59 \\
2.22\end{array}$ & $\begin{array}{l}-0.53 \\
-6.78\end{array}$ & $\begin{array}{l}-0.48 \\
-6.25\end{array}$ & $\begin{array}{l}-0.35 \\
-4.37\end{array}$ & $\begin{array}{l}-0.35 \\
-4.37\end{array}$ \\
\hline Inflation & $\begin{array}{r}-0.003 \\
-2.10\end{array}$ & $\begin{array}{r}-0.003 \\
-2.25\end{array}$ & $\begin{array}{r}-0.001 \\
-0.64\end{array}$ & $\begin{array}{r}-0.001 \\
-0.68\end{array}$ & $\begin{array}{r}-0.008 \\
-2.58\end{array}$ & $\begin{array}{r}-0.006 \\
-2.11\end{array}$ & $\begin{array}{r}-0.007 \\
-2.03\end{array}$ & $\begin{array}{r}-0.008 \\
-2.67\end{array}$ & $\begin{array}{r}-0.003 \\
-2.47\end{array}$ & $\begin{array}{r}-0.003 \\
-2.57\end{array}$ & $\begin{array}{r}-0.002 \\
-1.96\end{array}$ & $\begin{array}{l}-0.002 \\
-1.94\end{array}$ \\
\hline Inflation-squared & $\begin{array}{r}0.00004 \\
3.16\end{array}$ & $\begin{array}{r}0.00004 \\
3.33\end{array}$ & $\begin{array}{r}0.00001 \\
1.31\end{array}$ & $\begin{array}{r}0.00001 \\
1.35\end{array}$ & $\begin{array}{r}0.00005 \\
0.50\end{array}$ & $\begin{array}{r}0.00003 \\
0.31\end{array}$ & $\begin{array}{r}0.00006 \\
0.54\end{array}$ & $\begin{array}{r}0.00008 \\
0.81\end{array}$ & $\begin{array}{r}0.00004 \\
3.75\end{array}$ & $\begin{array}{r}0.00004 \\
3.40\end{array}$ & $\begin{array}{r}0.00002 \\
1.75\end{array}$ & $\begin{array}{r}0.00002 \\
1.65\end{array}$ \\
\hline $\begin{array}{l}\text { In (Primary School } \\
\text { Enrollment) }\end{array}$ & $\begin{array}{l}-0.58 \\
-4.68\end{array}$ & $\begin{array}{l}-0.56 \\
-4.63\end{array}$ & $\begin{array}{l}-0.73 \\
-6.67\end{array}$ & $\begin{array}{l}-0.72 \\
-6.52\end{array}$ & $\begin{array}{l}-0.24 \\
-1.95\end{array}$ & $\begin{array}{l}0.02 \\
0.15\end{array}$ & $\begin{array}{l}0.02 \\
0.11\end{array}$ & $\begin{array}{l}-0.13 \\
-0.83\end{array}$ & $\begin{array}{l}-0.05 \\
-1.07\end{array}$ & $\begin{array}{l}-0.13 \\
-2.86\end{array}$ & $\begin{array}{l}-0.23 \\
-3.72\end{array}$ & $\begin{array}{l}-0.26 \\
-4.07\end{array}$ \\
\hline Federal System & $\begin{array}{l}-0.19 \\
-3.14\end{array}$ & $\begin{array}{l}-0.15 \\
-2.41\end{array}$ & $\begin{array}{l}-0.20 \\
-1.37\end{array}$ & $\begin{array}{l}-0.20 \\
-1.38\end{array}$ & $\begin{array}{l}0.10 \\
1.06\end{array}$ & $\begin{array}{l}-0.02 \\
-0.25\end{array}$ & $\begin{array}{l}0.03 \\
0.32\end{array}$ & $\begin{array}{l}0.03 \\
0.28\end{array}$ & $\begin{array}{l}0.37 \\
6.20\end{array}$ & $\begin{array}{l}0.42 \\
7.02\end{array}$ & $\begin{array}{l}-0.35 \\
-3.26\end{array}$ & $\begin{array}{l}-0.30 \\
-2.66\end{array}$ \\
\hline In (\% pop'n urban) & $\begin{array}{l}0.30 \\
3.03\end{array}$ & $\begin{array}{l}0.33 \\
3.41\end{array}$ & $\begin{array}{l}0.43 \\
2.46\end{array}$ & $\begin{array}{l}0.43 \\
2.45\end{array}$ & $\begin{array}{l}0.38 \\
4.14\end{array}$ & $\begin{array}{l}0.25 \\
2.83\end{array}$ & $\begin{array}{l}-0.28 \\
-0.98\end{array}$ & $\begin{array}{l}-0.22 \\
-0.80\end{array}$ & $\begin{array}{l}-0.05 \\
-1.44\end{array}$ & $\begin{array}{l}-0.08 \\
-2.33\end{array}$ & $\begin{array}{l}0.35 \\
6.63\end{array}$ & $\begin{array}{l}0.32 \\
5.99\end{array}$ \\
\hline In (Capital inflows) & & $\begin{array}{r}-0.030 \\
-3.18\end{array}$ & & $\begin{array}{r}-0.005 \\
-0.71\end{array}$ & & & & & & & & \\
\hline In (Energy Consumption) & & & & & & $\begin{array}{l}-0.30 \\
-4.97\end{array}$ & & $\begin{array}{l}-0.55 \\
-4.34\end{array}$ & & & & \\
\hline In(UK Pa/Pm) & & & & & & & & & & $\begin{array}{l}0.92 \\
4.43\end{array}$ & & $\begin{array}{l}0.44 \\
1.99\end{array}$ \\
\hline Constant & $\begin{array}{l}3.11 \\
2.59\end{array}$ & $\begin{array}{l}2.41 \\
2.02\end{array}$ & $\begin{array}{l}9.40 \\
7.80\end{array}$ & $\begin{array}{l}9.23 \\
7.49\end{array}$ & $\begin{array}{l}10.71 \\
10.43\end{array}$ & $\begin{array}{l}10.27 \\
10.58\end{array}$ & $\begin{array}{r}10.06 \\
4.68\end{array}$ & $\begin{array}{l}7.04 \\
3.26\end{array}$ & $\begin{array}{l}5.85 \\
9.70\end{array}$ & $\begin{array}{l}0.11 \\
0.08\end{array}$ & $\begin{array}{l}10.16 \\
14.52\end{array}$ & $\begin{array}{l}7.34 \\
4.64\end{array}$ \\
\hline $\begin{array}{l}\text { Country Dummies? } \\
\text { Year Dummies }\end{array}$ & $\begin{array}{l}\text { No } \\
\text { No }\end{array}$ & $\begin{array}{l}\text { No } \\
\text { No }\end{array}$ & $\begin{array}{l}\text { Yes } \\
\text { No }\end{array}$ & $\begin{array}{l}\text { Yes } \\
\text { No }\end{array}$ & $\begin{array}{l}\text { No } \\
\text { No }\end{array}$ & $\begin{array}{l}\text { No } \\
\text { No }\end{array}$ & $\begin{array}{l}\text { Yes } \\
\text { No }\end{array}$ & $\begin{array}{l}\text { Yes } \\
\text { No }\end{array}$ & $\begin{array}{l}\text { No } \\
\text { No }\end{array}$ & $\begin{array}{l}\text { No } \\
\text { No }\end{array}$ & $\begin{array}{l}\text { Yes } \\
\text { No }\end{array}$ & $\begin{array}{l}\text { Yes } \\
\text { No }\end{array}$ \\
\hline $\begin{array}{l}\text { R-squared } \\
\text { Adi R-squared }\end{array}$ & $\begin{array}{r}0.338 \\
0.3018\end{array}$ & $\begin{array}{l}0.3699 \\
0.3321\end{array}$ & & & $\begin{array}{l}0.5015 \\
0.4717\end{array}$ & $\begin{array}{r}0.5608 \\
0.532\end{array}$ & $\begin{array}{l}0.5551 \\
0.5099\end{array}$ & $\begin{array}{l}0.5981 \\
0.5547\end{array}$ & $\begin{array}{l}0.3892 \\
0.3706\end{array}$ & $\begin{array}{l}0.4207 \\
0.4014\end{array}$ & & \\
\hline $\begin{array}{l}\text { Adj R-squared } \\
\text { Number of obs }\end{array}$ & $\begin{array}{r}0.318 \\
213\end{array}$ & $\begin{array}{l}.3211 \\
213\end{array}$ & 213 & 213 & $\begin{array}{l}0.4 / 17 \\
196\end{array}$ & $\begin{array}{r}0.532 \\
196\end{array}$ & $\begin{array}{r}0.5099 \\
196\end{array}$ & $\begin{array}{l}0.554 / \\
196\end{array}$ & $\begin{array}{r}0.3706 \\
374\end{array}$ & $\begin{array}{r}0.4014 \\
374\end{array}$ & 374 & 374 \\
\hline F-stat, Ho: All coeff's $=0$ & & & $\begin{array}{r}16.45 \\
373\end{array}$ & $\begin{array}{r}15.08 \\
34.2\end{array}$ & & & $\begin{array}{r}15.05 \\
3.05\end{array}$ & $\begin{array}{r}16.76 \\
2.33\end{array}$ & & & 20.5 & \\
\hline $\begin{array}{l}\text { F-stat, Ho: All dummies }=0 \\
\text { Number of groups }\end{array}$ & & & $\begin{array}{r}37.3 \\
8\end{array}$ & $\begin{array}{r}34.2 \\
8\end{array}$ & & & $\begin{array}{r}3.05 \\
8\end{array}$ & $\begin{array}{r}2.33 \\
8\end{array}$ & & & $\begin{array}{r}17 \\
8\end{array}$ & 8 \\
\hline Average obs. per group & & & 26.6 & 26.6 & & & 24.5 & 24.5 & & & 46.8 & 46.8 \\
\hline Hausman test statistic & & & -162.93 & -4516.99 & & & 16.79 & 19.09 & & & 138.18 & 110.81 \\
\hline
\end{tabular}


Table 5

Were Tariff Policy Determinants Different After Belle Epoque?

Dependent Variable:

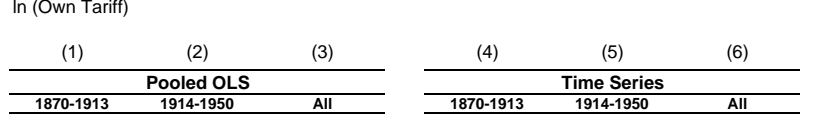

$\ln ($ Exports/GDP)

$\begin{array}{lll}0.06 & -0.60 & -0.29 \\ -1.01 & -8.82 & -0.41\end{array}$

\begin{tabular}{ccc} 
(7) & $(8)$ & $(9)$ \\
\hline & Cross Section & \\
\hline $1870-1913$ & 1914-1950 & All \\
\hline
\end{tabular}

\begin{tabular}{cc}
\multicolumn{1}{c}{$(10) \quad(11)$} & $(12)$ \\
\hline \multicolumn{3}{c}{ Panel Fixed Effects } \\
\hline $1870-1913 \quad$ All \\
\hline
\end{tabular}

In (GDP/capita)

In (Population)

In (Partner Tariffs)

In (Effective Distance)

$\begin{array}{lll}-0.01 & -8.82 & -0.29 \\ -0.13 & -0.81 & -0.13 \\ 0 & -0.41\end{array}$

$\begin{array}{lll}-1.03 & -5.41 & -4.50 \\ -0.15 & -0.62 & -0.36\end{array}$

$\begin{array}{lll}-0.13 & -0.57 & -0.32 \\ -1.98 & -7.16 & -6.18 \\ -0.27 & -0.77 & -0.44\end{array}$

$\begin{array}{lll}-0.07 & -0.46 & -0.35 \\ -1.03 & -5.41 & -5.72 \\ -0.16 & -0.87 & 0.49\end{array}$

$\begin{array}{llllll}0.24 & -0.83 & -0.39 & -0.54 & -0.63 & -0.55 \\ 2.03 & -9.01 & -5.48 & -2.49 & -3.32 & -5.18 \\ 0.34 & -0.96 & -0.44 & & -0.73 & -0.61\end{array}$

In (km Railways)

$\begin{array}{lll}0.18 & -0.73 & -0.35 \\ 2.56 & -8.40 & -7.44\end{array}$

$\begin{array}{lll}-2.49 & -3.32 & -5.18 \\ -0.76 & -0.73 & -0.61 \\ -0.18 & -0.92 & -0.64\end{array}$

$\begin{array}{lll}0.02 & -0.72 & -0.30 \\ 0.15 & -5.74 & -3.67 \\ 0.03 & -0.84 & -0.34\end{array}$

$\begin{array}{lll}-0.54 & -0.63 & -0.54 \\ -2.49 & -3.32 & -4.60 \\ -.164 & -1.03 & -0.60\end{array}$

$\begin{array}{llllll}0.18 & -0.73 & -0.35 & -0.18 & -0.92 & -0.64 \\ 2.56 & -8.40 & -7.44 & -0.75 & -3.98 & -6.58 \\ 0.55 & -1.51 & -0.81 & -0.54 & -1.91 & -1.50\end{array}$

Inflation

$\begin{array}{llllll}0.21 & 0.17 & 0.15 & -0.09 & 0.29 & 0.19 \\ 2.88 & 2.50 & 3.03 & -1.16 & 3.68 & 3.75 \\ \mathbf{0 . 3 0} & \mathbf{0 . 1 4} & \mathbf{0 . 1 4} & \mathbf{- 0 . 1 3} & \mathbf{0 . 2 5} & \mathbf{0 . 1 7}\end{array}$

$\begin{array}{llllll}-0.08 & -0.04 & -0.09 & -0.03 & -0.04 & -0.05 \\ -1.46 & -1.01 & -3.18 & -0.63 & -0.98 & -1.67 \\ -0.15 & -0.06 & -0.14 & -0.06 & -0.07 & -0.08\end{array}$

Inflation-squared

$\begin{array}{lll}-0.11 & 0.33 & 0.14 \\ -2.55 & 5.08 & 4.21 \\ -\mathbf{0 . 4 9} & \mathbf{0 . 7 8} & \mathbf{0 . 4 4}\end{array}$

$\begin{array}{lll}0.37 & 0.24 & 0.46 \\ 5.16 & 1.12 & 9.22 \\ 1.65 & 0.58 & 1.40\end{array}$

$\begin{array}{rrrrrr}-0.002 & -0.010 & -0.005 & -0.65 & 0.58 & 1.40 \\ -1.95 & -3.05 & -3.57 & -0.001 & -0.007 & -0.003 \\ -0.14 & -0.23 & -0.16 & -0.03 & -.12 & -0.16\end{array}$

$\begin{array}{lll}0.03 & -0.84 & -0.34 \\ 0.03 & -0.42 & -0.01\end{array}$

$\begin{array}{lll}0.36 & -2.99 & -0.13 \\ 0.09 & -0.88 & -0.02\end{array}$

$\begin{array}{lll}0.20 & -0.19 & 0.01 \\ 2.29 & -1.58 & 0.14 \\ \mathbf{0 . 2 8} & -\mathbf{0 . 1 6} & \mathbf{0 . 0 1}\end{array}$

$\begin{array}{lll}-0.18 & -0.92 & -0.58 \\ -0.75 & -.604 & -3.77\end{array}$

In (Primary School

$\begin{array}{lll}-0.14 & -3.05 & -3.57 \\ -0.23 & -0.16\end{array}$

Enrollment)

Federal System

In (\% pop'n urban)

Constant

Country Dummies?

R-squared

Adj R-squared

$\frac{T \text {-Tests on } \ln \text { (predicted tariffs): }}{1870-1913=1870-1950}$

$\begin{aligned} 1870-1913 & =1870-1950 \\ 1914-1950 & =1870-1950\end{aligned}$

$1914-1950=1870-1950$
$1870-1913=1914-1950$

$\begin{array}{rrrrrr}0.00004 & 0.00011 & 0.00005 & 0.00001 & 0.00011 & 0.00002 \\ 3.20 & 1.02 & 3.82 & 1.31 & 0.98 & 1.61\end{array}$

$\begin{array}{lll}-0.16 & 0.01 \\ 0.28 & -10 \\ 0.03 & 0.09 & -0.03\end{array}$

$\begin{array}{ll}-0.75 & -.48 \\ -0.48 & -6.04\end{array}$

$\begin{array}{lll}0.03 & 0.09 & -0.03 \\ 0.47 & 1.23 & -0.67\end{array}$

$\begin{array}{lll}0.06 & 0.16 & -0.05 \\ -0.24 & 0.12 & -0.10 \\ -.108 & 0.24\end{array}$

$\begin{array}{lll}-0.09 & -0.09 \\ -. .31 & -1.68 & -1.32 \\ -0.35 & -0.35 & 0.08\end{array}$

$\begin{array}{lll}-0.03 & -0.04 & -0.03 \\ -0.63 & -0.98 & -0.42 \\ 0.00 & 0.22 & 0.05\end{array}$

$\begin{array}{rrr}0.63 & -0.98 & -0.42 \\ 0.00 & \mathbf{0 . 2 2} & \mathbf{0 . 0 5}\end{array}$

-statistics are in italics

eta values are in bold 


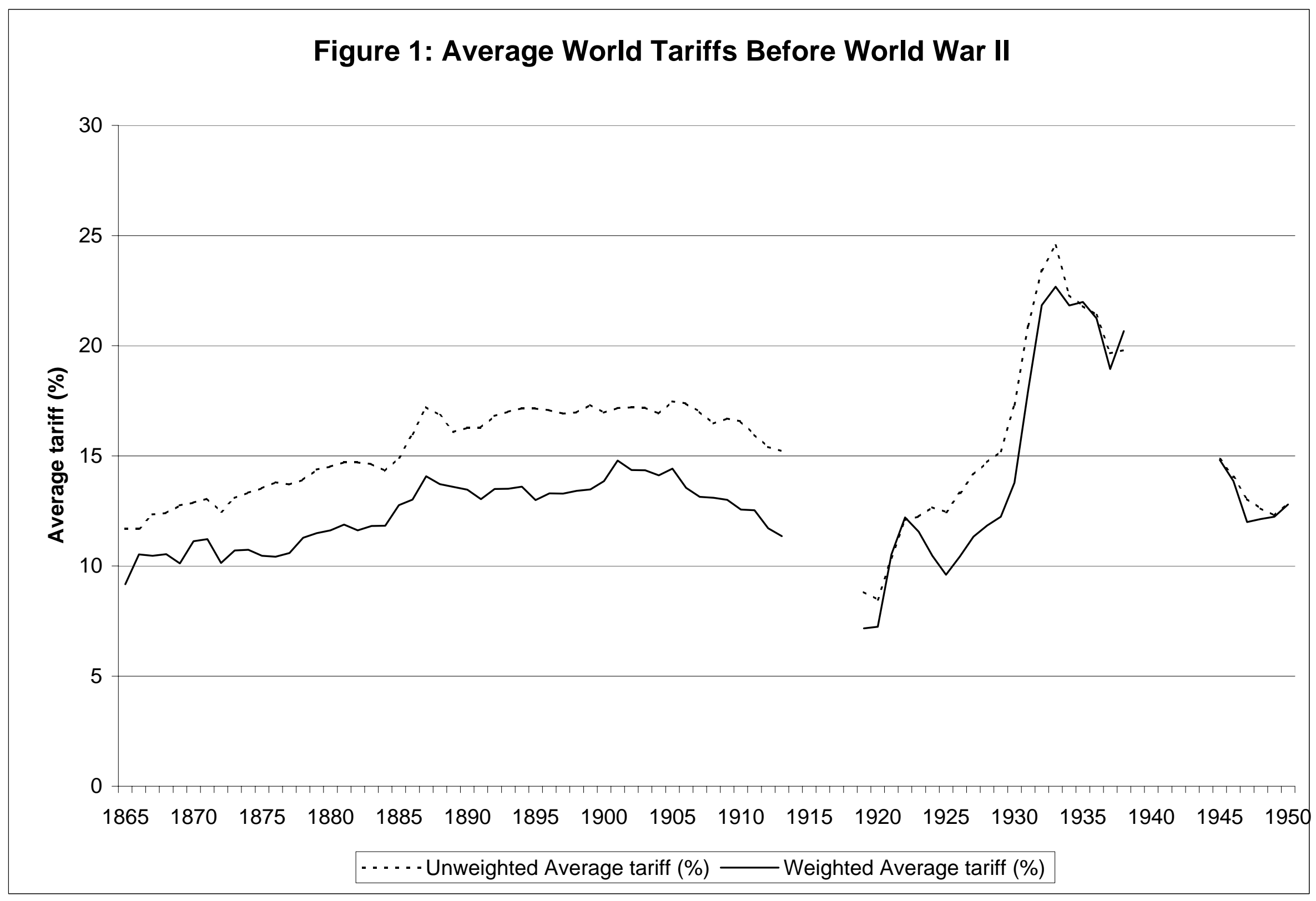




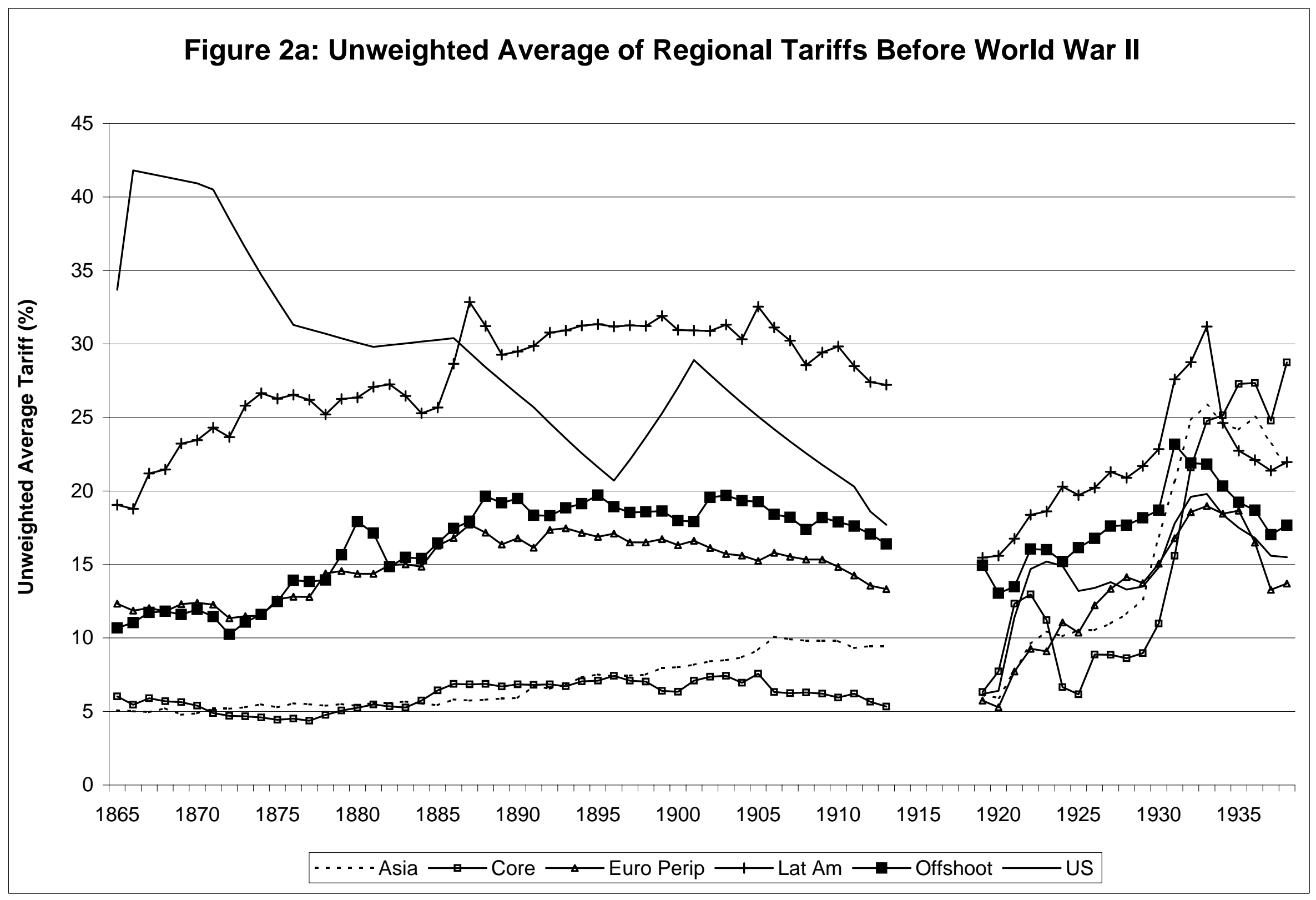




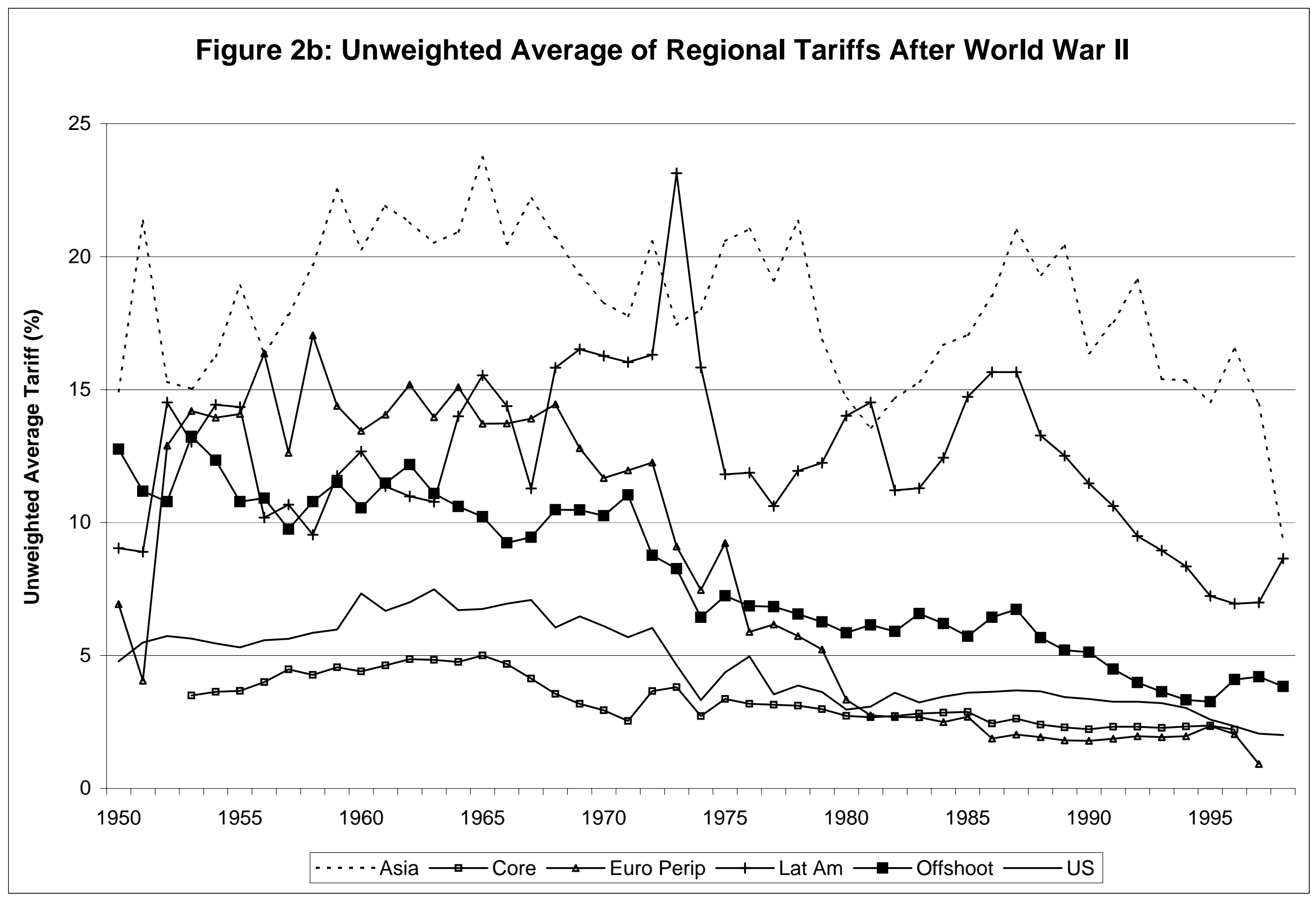




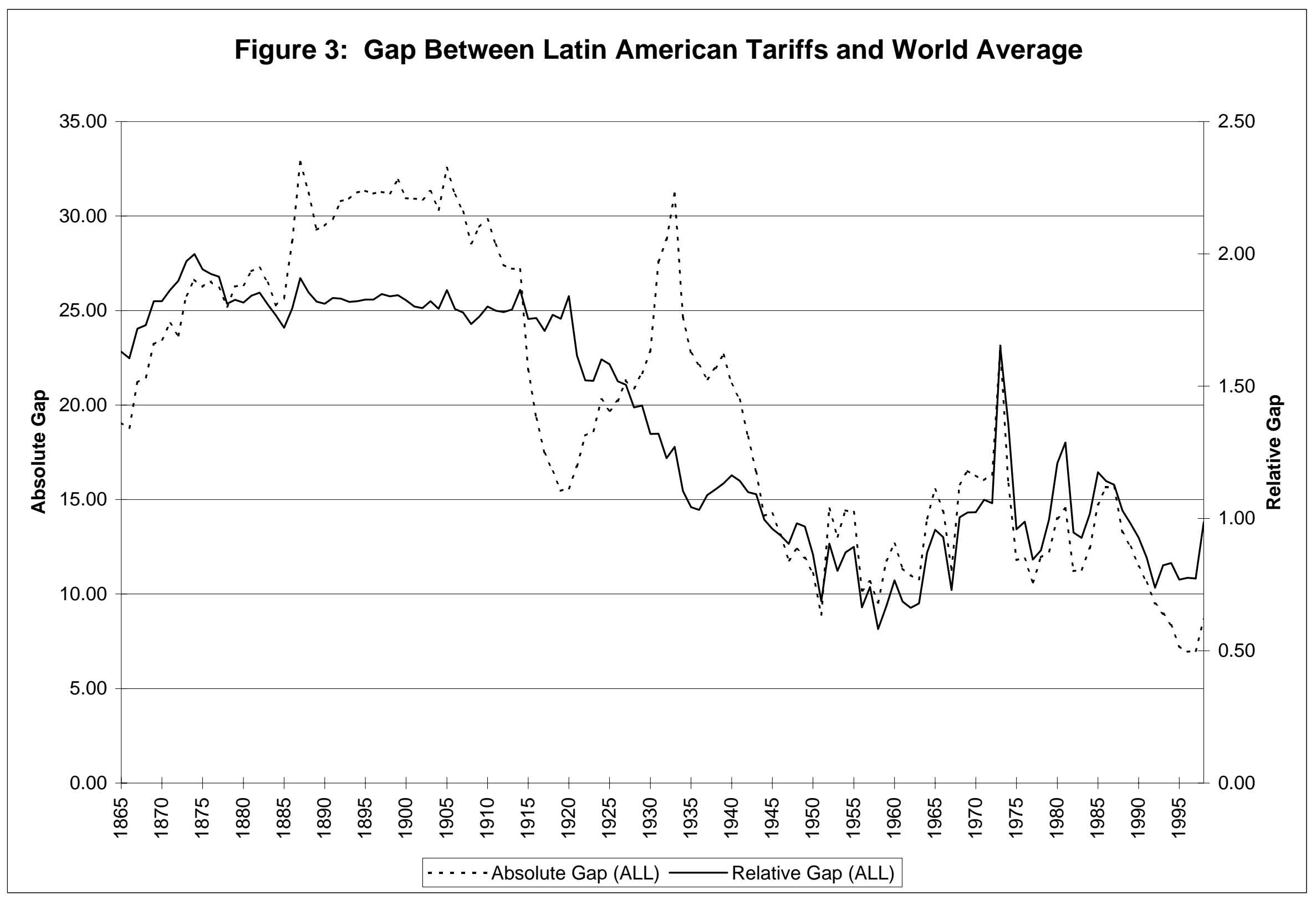




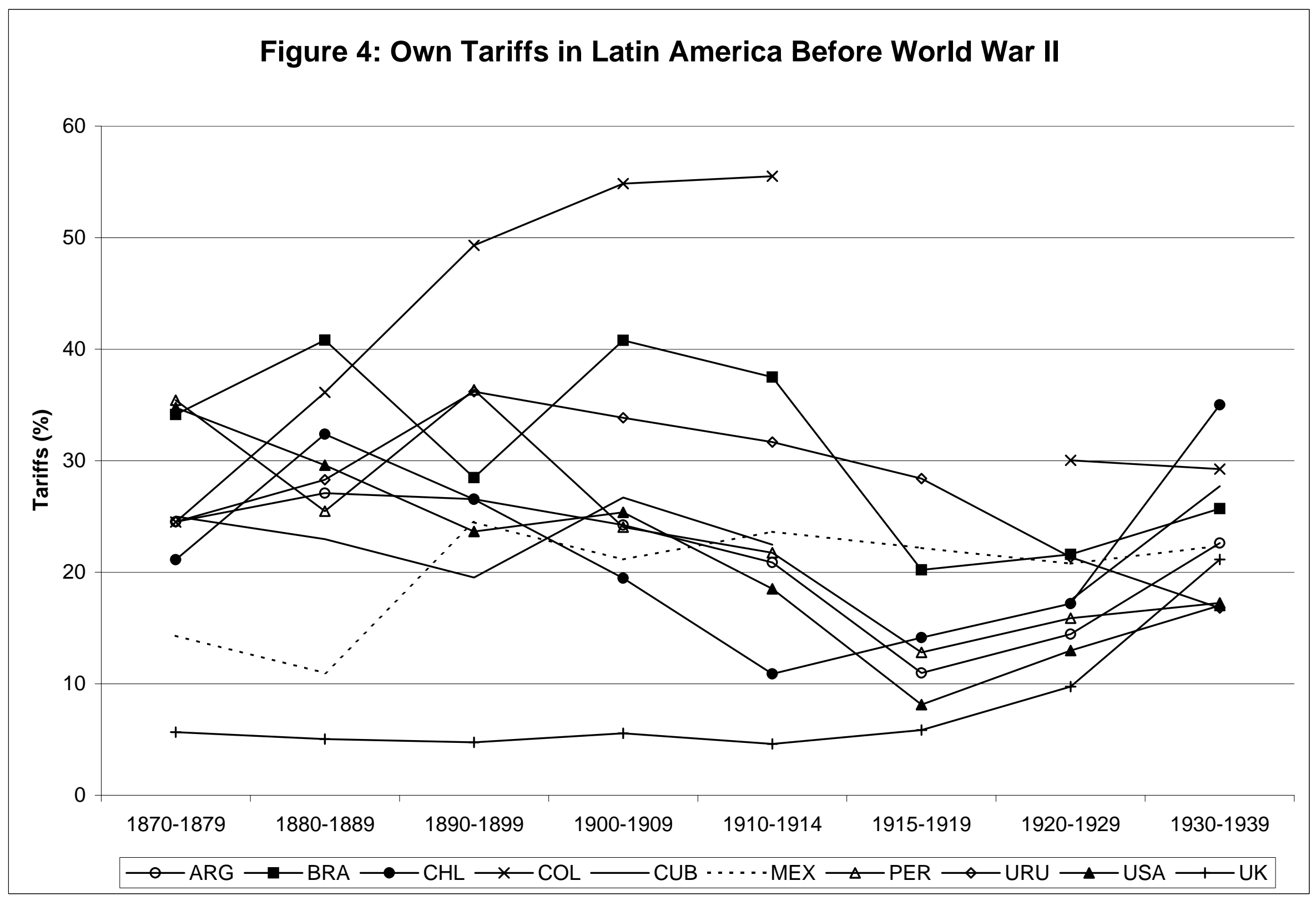




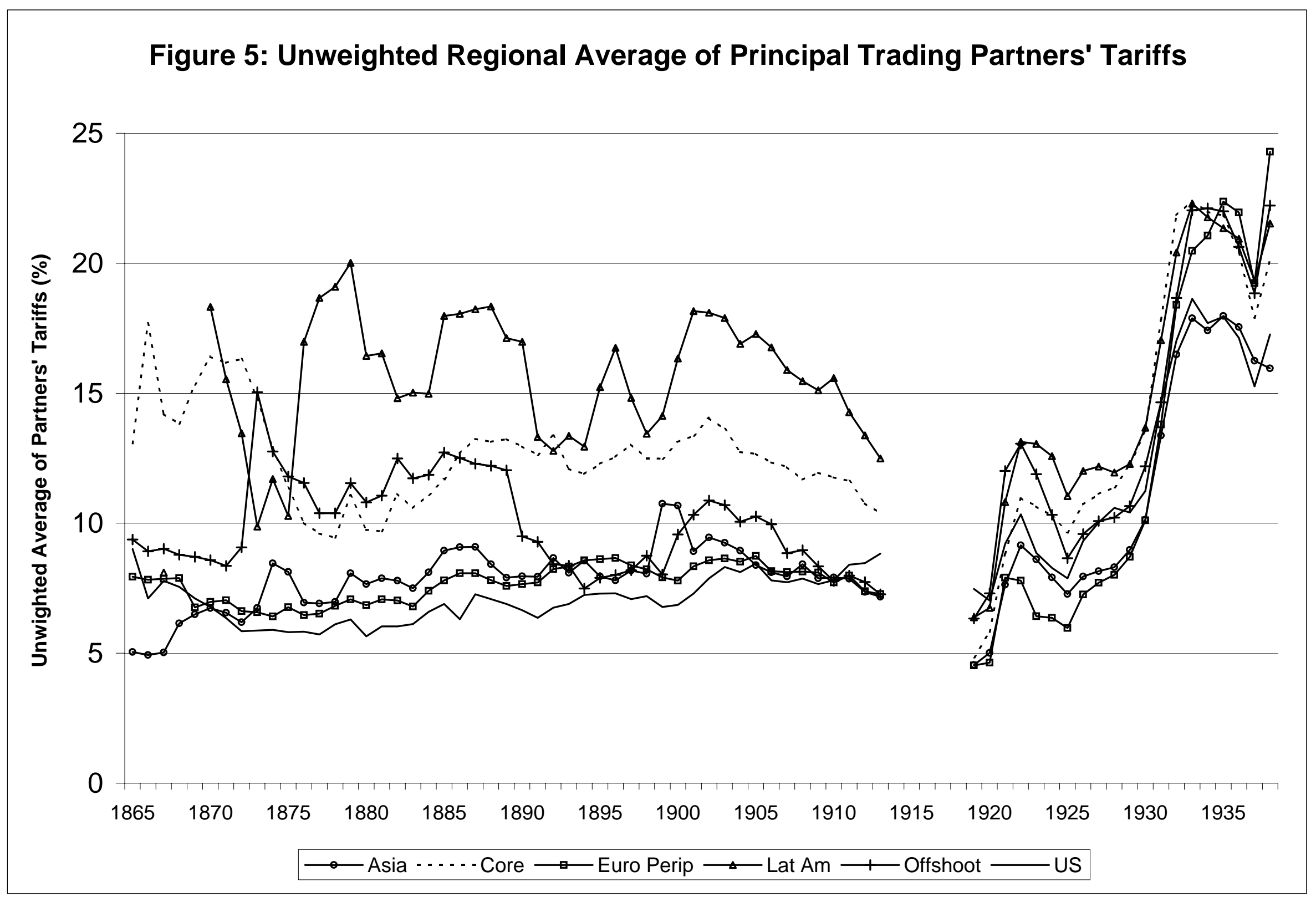

